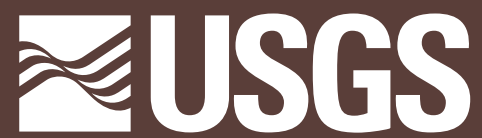

Prepared in cooperation with the

Ashokan Watershed Stream Management Program

\title{
Suspended-Sediment and Turbidity Responses to Sediment and Turbidity Reduction Projects in the Beaver Kill, Stony Clove Creek, and Warner Creek Watersheds, New York, 2010-14
}

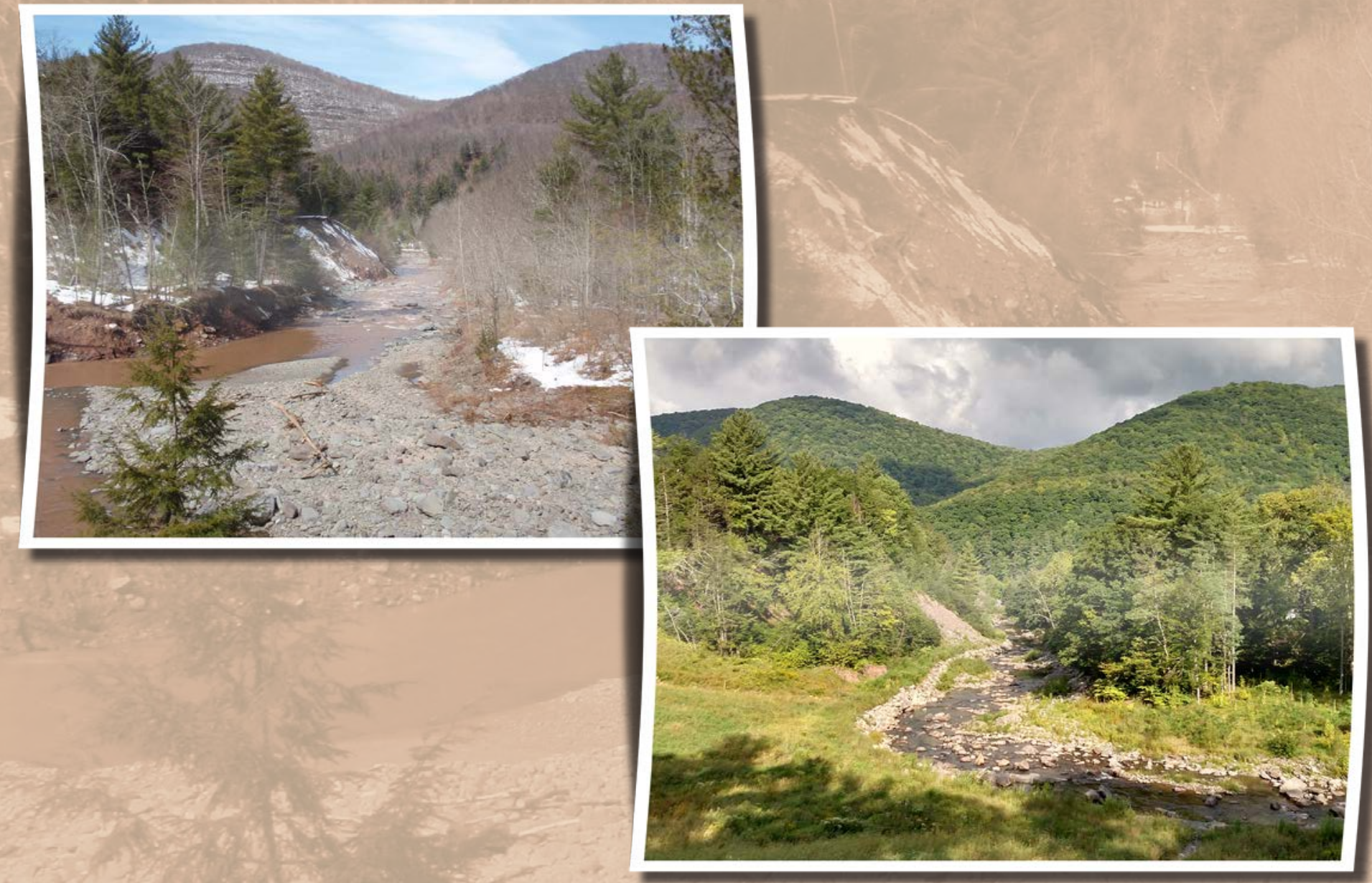

Scientific Investigations Report 2016-5157

U.S. Department of the Interior

U.S. Geological Survey 


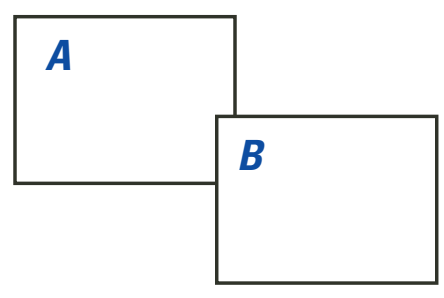

Cover. Stony Clove Creek at Chichester before, $A$, before and $B$, after a 2013 sediment and turbidity reduction project. Photographs by Wae Danyelle Davis. 


\section{Suspended-Sediment and Turbidity Responses to Sediment and Turbidity Reduction Projects in the Beaver Kill, Stony Clove Creek, and Warner Creek Watersheds, New York, 2010-14}

By Jason Siemion, Michael R. McHale, and Wae Danyelle Davis

Prepared in cooperation with the

Ashokan Watershed Stream Management Program

Scientific Investigations Report 2016-5157 


\title{
U.S. Department of the Interior SALLY JEWELL, Secretary
}

\section{U.S. Geological Survey Suzette M. Kimball, Director}

\author{
U.S. Geological Survey, Reston, Virginia: 2016
}

For more information on the USGS - the Federal source for science about the Earth, its natural and living resources, natural hazards, and the environment-visit http://www.usgs.gov or call 1-888-ASK-USGS.

For an overview of USGS information products, including maps, imagery, and publications, visit http://store.usgs.gov.

Any use of trade, firm, or product names is for descriptive purposes only and does not imply endorsement by the U.S. Government.

Although this information product, for the most part, is in the public domain, it also may contain copyrighted materials as noted in the text. Permission to reproduce copyrighted items must be secured from the copyright owner.

Suggested citation:

Siemion, Jason, McHale, M.R., and Davis, W.D., 2016, Suspended-sediment and turbidity responses to sediment and turbidity reduction projects in the Beaver Kill, Stony Clove Creek, and Warner Creek Watersheds, New York, 2010-14: U.S. Geological Survey Scientific Investigations Report 2016-5157, 28 p., https://doi.org/10.3133/sir20165157.

ISSN 2328-0328 (online) 


\section{Acknowledgments}

We gratefully acknowledge the support for this project provided by the Ashokan Watershed Stream Management Program. We also would like to extend our appreciation to John Byrnes and Daniel Edwards of the U.S. Geological Survey for their help with field work, to Hannah Ingleston of the U.S. Geological Survey for help processing samples, and to Gary Wall and Tim Hoffman of the U.S. Geological Survey for their help with sediment-turbidity regression development. Thank you to John Jastram and Kirk Smith of the U.S. Geological Survey for their constructive reviews and suggestions for improvement of this manuscript. 



\section{Contents}

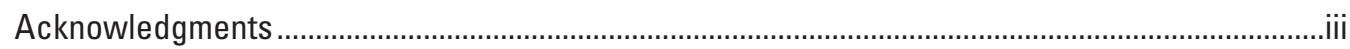

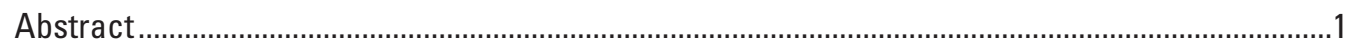

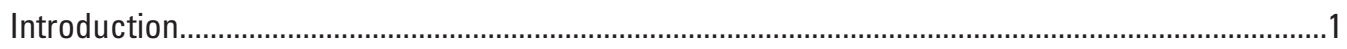

Previous Watershed Assessments.....................................................................................

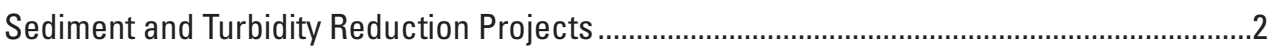

Assessment Objectives and Approach ……………........................................................

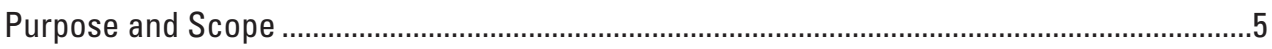

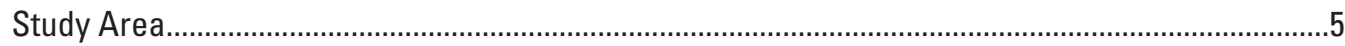

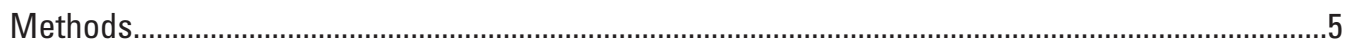

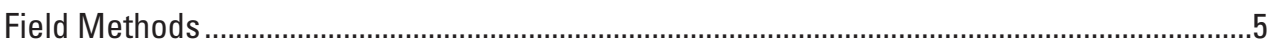

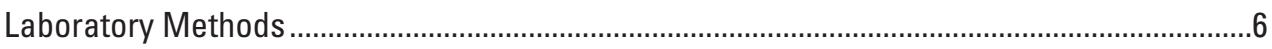

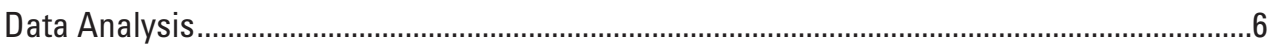

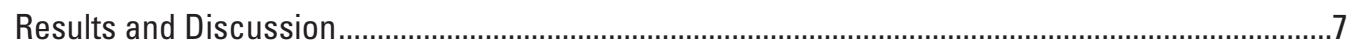

Streamflow Conditions...................................................................................................

Turbidity-Suspended-Sediment Concentration Regressions ..................................................

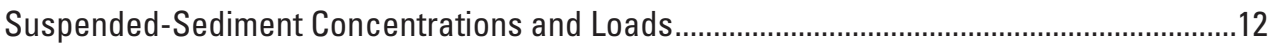

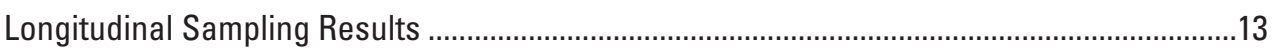

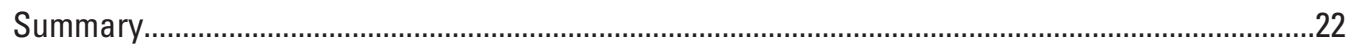

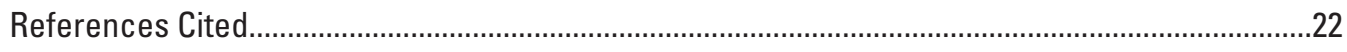

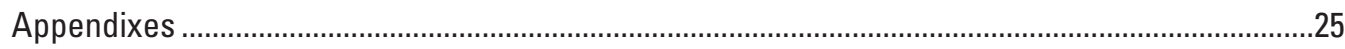

\section{Figures}

1. Location map showing the Beaver Kill, Stony Clove Creek, and Warner Creek watersheds within the Ashokan Reservoir watershed, New York.

2. Map showing streamgages, hillslope failures, and the extent and locations of sediment and turbidity reduction projects (STRPs) in the Stony Clove Creek and Warner Creek watersheds, New York.

3. Aerial photograph showing Chichester reaches 1, 2, and 3 of Stony Clove Creek, New York.

4. Photographs showing reach 1 of Stony Clove Creek, New York, $A$, before and $B$, after the 2012 sediment and turbidity reduction project.

5. Graph showing daily mean streamflow and suspended-sediment samples for the period of record at Stony Clove Creek below Ox Clove at Chichester, New York

6. Boxplots showing daily mean streamflow before and after sediment and turbidity reduction projects at the $A$, Stony Clove Creek below 0x Clove at Chichester, New York, and $B$, Warner Creek near Chichester, New York, streamgages.

7. Graphs showing study period streamflow duration curves for $A$, Beaver Kill, $B$, Stony Clove Creek, and $C$, Warner Creek, New York, showing daily mean streamflow at which discrete samples were collected, and daily mean streamflow at which longitudinal sampling was conducted.

8. Graphs showing relations between in-situ turbidity and suspended-sediment concentration (SSC) at the $A$, Beaver Kill at Mount Tremper, New York, $B$, Stony Clove Creek below 0x Clove at Chichester, New York (DTS-12 turbidity sensor), $C$, Stony Clove Creek below 0x Clove at Chichester, New York (Hach Surface Scatter 7 turbidity sensor), and $D$, Warner Creek near Chichester, New York, streamgages .....11 
9. Graph showing suspended-sediment loads during sediment and turbidity reduction projects (STRP) and during non-STRP periods for the $A$, Beaver Kill at Mount Tremper, New York, B, Stony Clove Creek below Ox Clove at Chichester, New York, $C$, Warner Creek near Chichester, New York, streamgages.

10. Plots showing $A$, daily mean suspended-sediment concentration (SSC) and streamflow and $B$, daily mean SSC as a function of daily mean streamflow daily mean and streamflow at the Beaver Kill at Mount Tremper, New York, streamgage .....14

11. Plots showing $A$, daily mean suspended-sediment concentration (SSC) and streamflow and $B$, daily mean SSC as a function of daily mean streamflow before and after the sediment and turbidity reduction projects at the Stony Clove Creek below 0x Clove at Chichester, New York, streamgage.

12. Box plots showing daily mean suspended-sediment concentration for daily mean streamflow at Stony Clove Creek below 0x Clove at Chichester, New York, before the sediment turbidity reduction projects (STRP), between the 2012 and 2013 STRPs, and after the 2013 STRP

13. Plots showing $A$, daily mean suspended-sediment concentration (SSC) and streamflow and $B$, daily mean SSC as a function of daily mean streamflow before and after the sediment and turbidity reduction project at the Warner Creek near Chichester, New York, streamgage.

14. Box plots showing daily mean suspended-sediment concentration for daily mean streamflow at the Warner Creek near Chichester, New York, streamgage before and after the 2013 sediment turbidity reduction project

15. Map showing longitudinal sampling sites, bank erosion, and fine sediment exposures in the Beaver Kill watershed, New York.

16. Map showing longitudinal sampling sites, bank erosion, and fine sediment exposures in the Stony Clove Creek watershed, New York

17. Map showing longitudinal sampling sites and fine sediment exposures in the Warner Creek watershed, New York.

\section{Tables}

1. Sediment and turbidity reduction projects in the Stony Clove Creek and Warner Creek watersheds, New York, 2012-14

2. Watershed characteristics upstream from U.S. Geological Survey streamgages on Beaver Kill, Stony Clove Creek, and Warner Creek, New York

3. Stream feature inventory results for Beaver Kill, Stony Clove Creek, and Warner Creek, New York.

4. Details of regressions of daily mean suspended-sediment concentrations on daily mean streamflows

5. Details of discrete turbidity-suspended-sediment concentration regressions

2-1. Longitudinal sampling sites and U.S. Geological Survey streamgages in the Beaver Kill, Stony Clove Creek, and Warner Creek watersheds, New York.

2-2. Instantaneous streamflow at monitoring stations in the Beaver Kill, Stony Clove Creek, and Warner Creek watersheds, New York. 


\section{Conversion Factors}

U.S. customary units to International System of Units

\begin{tabular}{lcl}
\hline \multicolumn{1}{c}{ Multiply } & \multicolumn{1}{c}{ By } & \multicolumn{1}{c}{ To obtain } \\
\hline cubic foot per second $\left(\mathrm{ft}^{3} / \mathrm{s}\right)$ & 0.02832 & cubic meter per second $\left(\mathrm{m}^{3} / \mathrm{s}\right)$ \\
foot $(\mathrm{ft})$ & 0.3048 & meter $(\mathrm{m})$ \\
foot per mile $(\mathrm{ft} / \mathrm{mi})$ & 0.1894 & meter per kilometer $(\mathrm{m} / \mathrm{km})$ \\
gallon $(\mathrm{gal})$ & 3.785 & liter $(\mathrm{L})$ \\
mile $(\mathrm{mi})$ & 1.609 & kilometer $(\mathrm{km})$ \\
square mile $\left(\mathrm{mi}^{2}\right)$ & 259.0 & hectare $(\mathrm{ha})$ \\
square mile $\left(\mathrm{mi}^{2}\right)$ & 2.590 & square kilometer $\left(\mathrm{km}^{2}\right)$ \\
ton, short $(2,000 \mathrm{lb})$ & 0.9072 & ton, metric $(\mathrm{t})$ \\
yard $(\mathrm{yd})$ & 0.9144 & meter $(\mathrm{m})$ \\
\hline
\end{tabular}

\section{Datum}

Vertical coordinate information is referenced to North American Vertical Datum of 1988 (NAVD 88).

Horizontal coordinate information is referenced to North American Datum of 1983 (NAD 83).

Elevation, as used in this report, refers to distance above the vertical datum.

\section{Supplemental Information}

Suspended-sediment concentrations are given in milligrams per liter (mg/L).

Nephelometric turbidity unit (NTU) is measure of turbidity in a water sample, roughly equivalent to formazin turbidity unit (FTU) and Jackson turbidity unit (JTU). 


\section{Abbreviations}

$\begin{array}{ll}\text { ANCOVA } & \text { analysis of covariance } \\ \text { AWSMP } & \text { Ashokan Watershed Stream Management Program } \\ \text { EWI } & \text { equal-width depth-integrated } \\ \text { FNU } & \text { formazin nephelometric units } \\ \text { NYCDEP } & \text { New York City Department of Environmental Protection } \\ r^{2} & \text { coefficient of determination } \\ \text { SS7 } & \text { Hach Surface Scatter 7 } \\ \text { SSC } & \text { suspended-sediment concentration } \\ \text { STRP } & \text { sediment and turbidity reduction project } \\ \text { USGS } & \text { U.S. Geological Survey }\end{array}$




\title{
Suspended-Sediment and Turbidity Responses to Sediment and Turbidity Reduction Projects in the Beaver Kill, Stony Clove Creek, and Warner Creek Watersheds, New York, 2010-14
}

\author{
By Jason Siemion, ${ }^{1}$ Michael R. McHale, ${ }^{1}$ and Wae Danyelle Davis ${ }^{2}$
}

\begin{abstract}
Suspended-sediment concentrations (SSCs) and turbidity were monitored within the Beaver Kill, Stony Clove Creek, and Warner Creek tributaries to the upper Esopus Creek in New York, the main source of water to the Ashokan Reservoir, from October 1, 2010, through September 30, 2014. The purpose of the monitoring was to determine the effects of suspended-sediment and turbidity reduction projects (STRPs) on SSC and turbidity in two of the three streams; no STRPs were constructed in the Beaver Kill watershed. During the study period, four STRPs were completed in the Stony Clove Creek and Warner Creek watersheds. Daily mean SSCs decreased significantly for a given streamflow after the STRPs were completed. The most substantial decreases in daily mean SSCs were measured at the highest streamflows. Background SSCs, as measured in water samples collected in upstream reference stream reaches, in all three streams in this study were less than 5 milligrams per liter during low and high streamflows. Longitudinal stream sampling identified stream reaches with failing hillslopes in contact with the stream channel as the primary sediment sources in the Beaver Kill and Stony Clove Creek watersheds.
\end{abstract}

\section{Introduction}

Suspended-sediment concentrations (SSCs) and turbidity are primary water-quality concerns in the Ashokan Reservoir, which is part of the New York City water-supply system, and the Esopus Creek upstream from the reservoir, which is the primary tributary to the Ashokan Reservoir (fig. 1). Turbidity from suspended sediment entrained during stream-channel erosion and from mass failure of steep cut banks typically on the outside of meanders is the highest water-quality concern in

${ }^{1}$ U.S. Geological Survey.

${ }^{2}$ New York City Department of Environmental Protection. the Ashokan Reservoir watershed. The New York City watersupply system provides more than 9 million people with clean drinking water each day from the world's largest unfiltered water-supply system (New York City, 2014).

The Ashokan Watershed Stream Management Program (AWSMP) is a New York City water-supply watershed protection program funded by New York City Department of Environmental Protection (NYCDEP) and staffed by Ulster County Soil and Water Conservation District, Cornell Cooperative Extension of Ulster County, and NYCDEP employees. The AWSMP mission is to foster science-based, multiobjective stream management practices with a particular emphasis on protecting and restoring water quality. The NYCDEP is required to fund stream restoration projects targeted to reduce turbidity in the Ashokan Reservoir watershed as part of the Federal and New York State determination that allows NYCDEP to operate this portion of the New York City water supply without filtration (U.S. Environmental Protection Agency, 2007).

\section{Previous Watershed Assessments}

Suspended sediment and turbidity have been known problems in the Ashokan Reservoir since it was constructed in 1915 (Alcott and others, 2013), and elevated turbidity levels have been measured in the reservoir after high streamflow events (Effler and others, 1998). Mukundan and others (2013) identified season, spatial patterns in precipitation, antecedent soil moisture, stream power during storms, geologic sources of sediment, and streamflow regime (timing and magnitude of streamflow) as factors affecting storm turbidity levels in tributaries to the upper Esopus Creek, including Beaver Kill and Stony Clove Creek. A potential effect of future climate scenarios, such as warmer and wetter winters, on sediment loading and associated turbidity to the reservoir includes increased turbidity values (Samal and others, 2013). Stony Clove Creek has been identified as the primary tributary source and Beaver Kill as a secondary tributary source of suspended sediment and turbidity to the upper Esopus Creek (McHale and Siemion, 2014). 


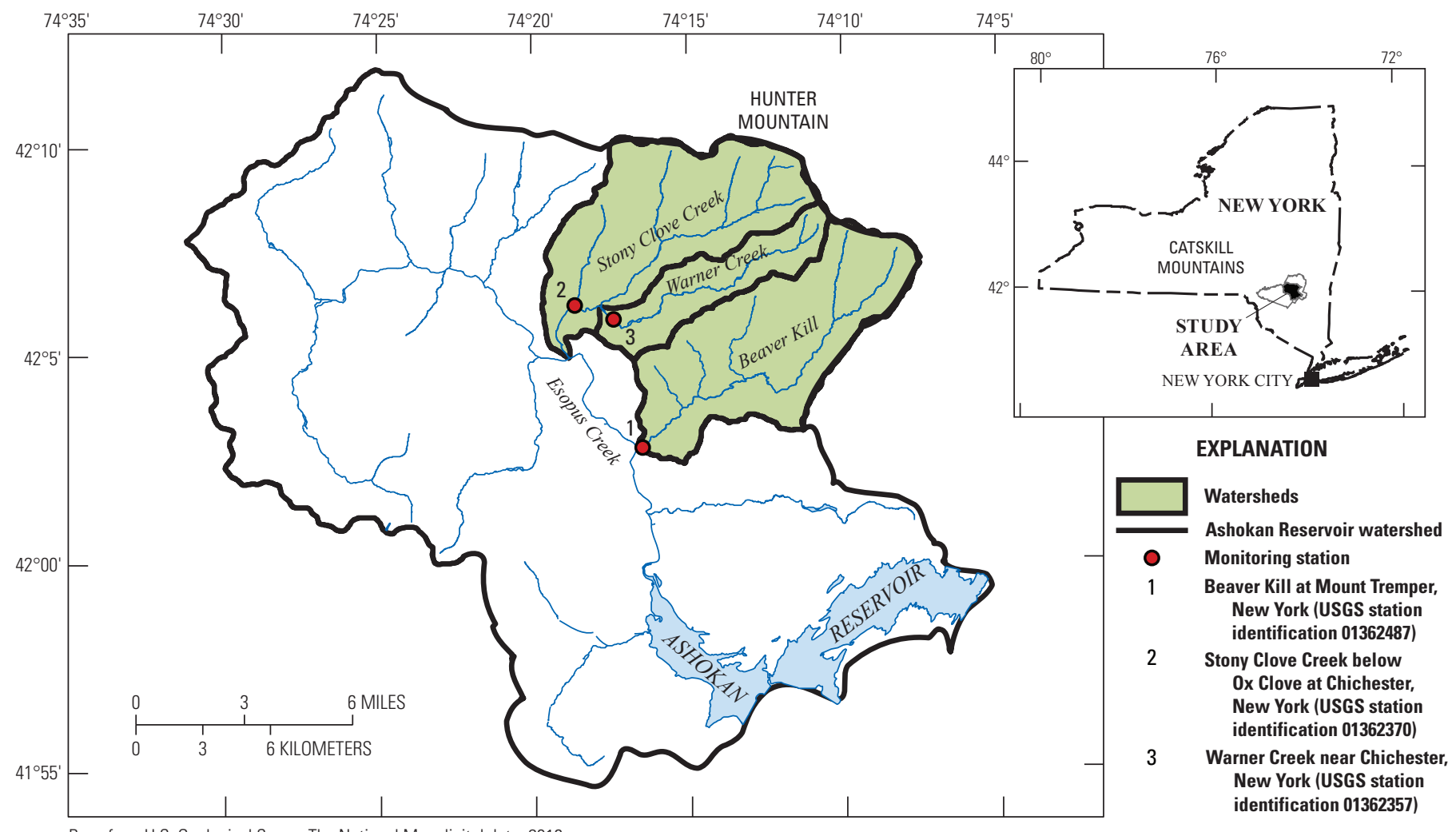

Figure 1. The Beaver Kill, Stony Clove Creek, and Warner Creek watersheds within the Ashokan Reservoir watershed, New York.

Stream corridor geomorphic assessments can be used to evaluate the stability of stream reaches, to identify stream erosion hazards, and to identify sources of stream water suspended sediment and turbidity; however, geomorphic assessments alone cannot quantify the sediment loads that these sources deliver to the stream. The AWSMP completed stream corridor geomorphic assessments in the Beaver Kill in 2010 and 2012 and in Stony Clove Creek in 2001 and 2013. The NYCDEP led a stream geomorphic assessment of Warner Creek (principal tributary to Stony Clove Creek) in 2010 and repeated the assessment in 2011 and 2012 to monitor effects of extreme flooding on stream-channel morphology and sediment sources (Davis and Callinan, 2013). The results of the assessments indicated that Stony Clove Creek and Warner Creek had distributed and concentrated sources of sediment and associated turbidity (Green County Soil and Water Conservation District, 2005; Ashokan Watershed Stream Management Program, 2015; Davis and others, 2015). Distributed sources are mobilized by surface runoff and stream-channel erosion during storms and snowmelt (Cornell Cooperative Extension of Ulster County, 2007). Concentrated sources of suspended sediment in Catskill Mountain streams are mobilized by hillslope mass failures adjacent to streams, particularly where these areas intersect glaciolacustrine deposits and glacial till, which are the primary in-stream and terrestrial sources of suspended sediment in the Ashokan Reservoir watershed (Cornell Cooperative Extension of Ulster County, 2007; Davis and others, 2009).

Multiple student research projects have been completed in Stony Clove Creek watershed; published abstracts include information on bedrock control of surficial topography and drainage patterns (Haskins and Vollmer, 2013), glacial history and stratigraphy (De Simone and others, 2013; Staley and others, 2013), historical three dimensional modeling of erosion for sediment volume analysis (Hewes and McGlinn, 2013), fluvial geomorphology of Warner Creek (Davis and Callinan, 2013; Neel and others, 2013), the role of groundwater and surface water on slope stability (Kiekhaefer and Chowdhury, 2013), and the effects of groundwater on slope failures (Baglia and O'Connell, 2014). Potential sediment sources were identified in the stream management plans for Beaver Kill (Ashokan Watershed Stream Management Program, 2015) and Stony Clove Creek (Green County Soil and Water Conservation District, 2005) and in the assessment of Warner Creek (Davis and Callinan, 2013).

\section{Sediment and Turbidity Reduction Projects}

The NYCDEP partnered with the AWSMP and the U.S. Department of Agriculture Natural Resource 
Conservation Service to design and construct four sediment and turbidity reduction projects (STRPs) in Stony Clove Creek and Warner Creek between 2012 and 2014 (fig. 2; table 1). A proposed Beaver Kill STRP was not constructed because of a change in watershed management priorities. The Beaver Kill thus served as an untreated control watershed for comparison to the treatments in Stony Clove Creek and Warner Creek. Stony Clove reaches 1, 2, and 3, and Warner Creek site 5 were selected for STRP construction on the basis of the stream geomorphic assessments, which identified these reaches as chronic sources of sediment and turbidity, and on the basis of destructive impacts of Tropical Storms Irene and Lee in 2011. The STRPs were multiobjective stream restoration projects intended to protect transportation infrastructure and to restore properly functioning channel planform and dimensions, flood plain connectivity, bedload sediment transport function, and aquatic habitat. The STRPs also were intended to help reduce SSC and associated turbidity at the reach scale during low to moderate streamflow.

The 2012 and 2013 Stony Clove Creek and Warner Creek STRPs treated about 945 meters (m) of deeply incised stream channel and adjacent hillslope mass failures discontinuously contacting glacial till and glaciolacustrine deposits (fig. 3). The 2013-14 STRP at the Stony Clove Creek and Warner Creek confluence (fig. 2; table 1) treated 396 m of degraded stream with about a 3-m headcut into glacial till. The headcut had migrated upstream in Stony Clove Creek past the confluence with Warner Creek during the large storms of 2011 and had the potential to exhume extensive deposits of sediment upstream if not treated.

The STRP methods included restoring streambed elevation and flood plain access; installing in-stream hydraulic and grade control structures such as boulder constructed cross vanes, rock vanes, and constructed riffles; and armoring streambanks with rock. Hillslope stabilization included regrading slopes, installing surface and subsurface drainage systems, and importing fill and restoring stabilizing vegetation (fig. 4).

In addition to ongoing annual and streamflow eventbased channel morphometric monitoring at the STRPs by AWSMP staff, the U.S. Geological Survey (USGS) measured changes in SSC and turbidity values to assess the effectiveness of the STRPs. The STRPs in Stony Clove Creek and Warner Creek were ideal candidates for this type of analysis because the streams drain small watersheds that are substantial contributors of suspended sediment to the Esopus Creek and Ashokan Reservoir and contain clearly defined areas of bank instability and slope failures. In addition, the data collected from these two watersheds could be placed in the context of an existing ten year record of SSC collected in the Stony Clove Creek by previous water-quality monitoring projects (McHale and Siemion, 2010, 2014) and compared with data collected in the Beaver Kill where no STRPs were constructed.

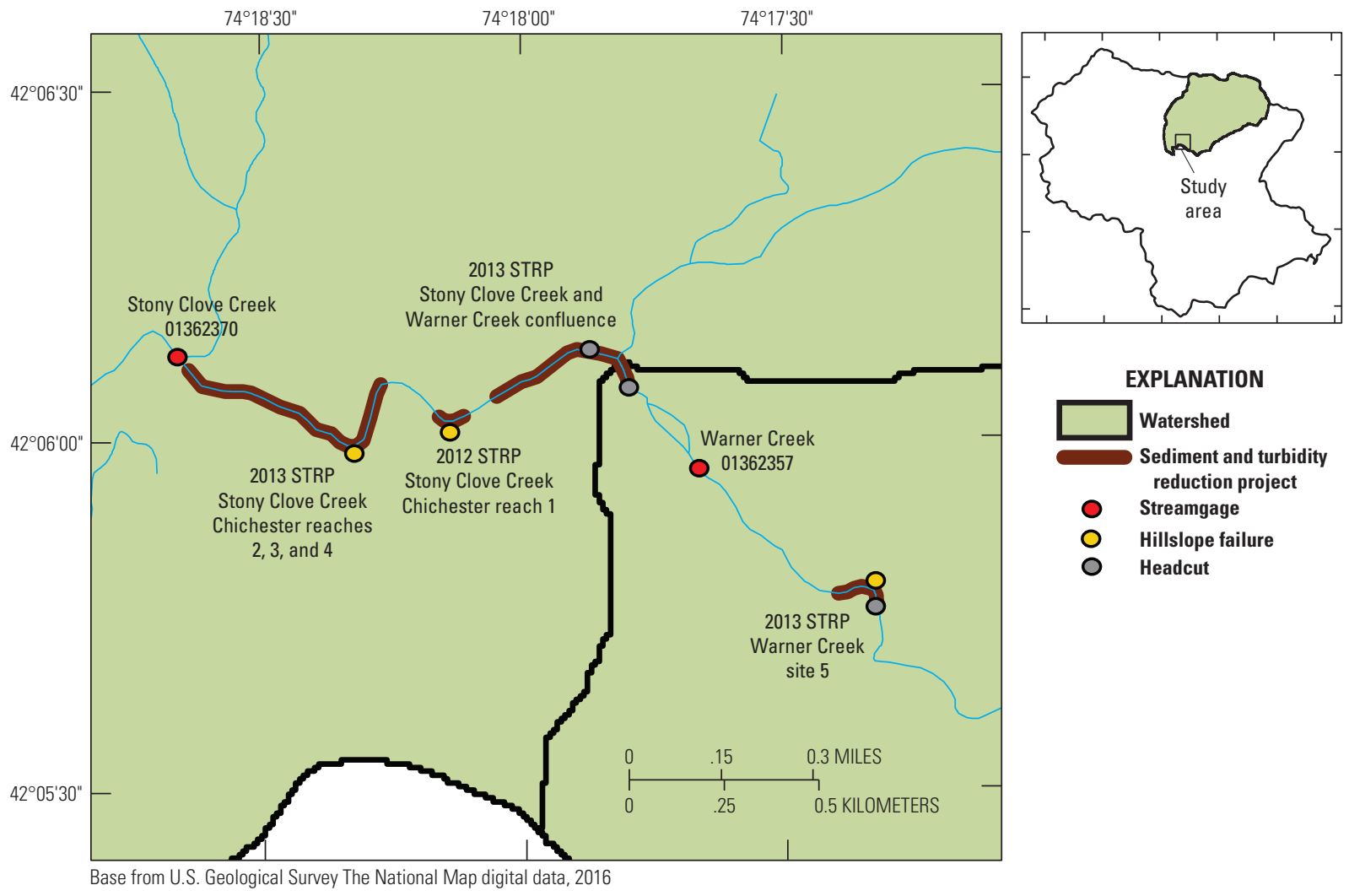

Figure 2. Streamgages, hillslope failures, and the extent and locations of sediment and turbidity reduction projects (STRPs) in the Stony Clove Creek and Warner Creek watersheds, New York. 
Table 1. Sediment and turbidity reduction projects in the Stony Clove Creek and Warner Creek watersheds, New York, 2012-14.

[STRP, sediment and turbidity reduction project; m, meters; GL, glaciolacustrine silt/clay; GT, glacial till; see figure 2 for STRP locations]

\begin{tabular}{lcccc}
\hline \multicolumn{1}{c}{ STRP } & \multicolumn{1}{c}{ Project date } & $\begin{array}{c}\text { Length } \\
(\mathbf{m})\end{array}$ & Sediment sources & Cost \\
\hline $\begin{array}{l}\text { Stony Clove Creek reach 1 } \\
\text { (2012 STRP) }\end{array}$ & $8 / 15 / 2012$ through 9/30/2012 & 198 & $\begin{array}{c}\text { Stream bank and hillslope erosional } \\
\text { contact with GL and GT }\end{array}$ & $\$ 1,020,369$ \\
$\begin{array}{l}\text { Stony Clove Creek reaches 2-4 } \\
\text { (2013 STRP) }\end{array}$ & $7 / 15 / 2013$ through 10/31/2013 & 503 & $\begin{array}{c}\text { Stream bank, bed and hillslope erosional } \\
\text { contact with GL and GT }\end{array}$ & $\$ 1,547,182$ \\
$\begin{array}{l}\text { Warner Creek site 5 } \\
\text { (2013 STRP) }\end{array}$ & 6/15/2013 through 9/15/2013 & 244 & $\begin{array}{c}\text { Stream bank, bed and hillslope erosional } \\
\text { contact with GL and GT }\end{array}$ & $\$ 495,465$ \\
$\begin{array}{l}\text { Stony Clove and Warner Creek } \\
\text { confluence (2013 STRP) }\end{array}$ & $\begin{array}{c}10 / 29 / 2013 \text { through 1/10/2014 and } \\
6 / 23 / 2014 \text { through 11/20/2014 }\end{array}$ & 396 & $\begin{array}{c}\text { Stream bank and bed erosional contact } \\
\text { with GL and GT }\end{array}$ & $\$ 1,585,454$ \\
\hline
\end{tabular}

\section{Assessment Objectives and Approach}

The objectives of this project were to quantify SSC, turbidity values, and suspended-sediment loads before, during, and after construction of STRPs that were intended to improve water quality in the Stony Clove Creek and Warner Creek watersheds. The specific approach components of the project were as follows: (1) quantify the suspended-sediment load, SSC, and turbidity values in the Beaver Kill, Stony Clove Creek, and Warner Creek watersheds before and after construction of STRPs; (2) compare the differences in the suspended-sediment loads, SSC, and turbidity values before and after the STRPs were completed; and (3) identify chronic and episodic sources of sediment in the stream reaches by longitudinal stream sampling.

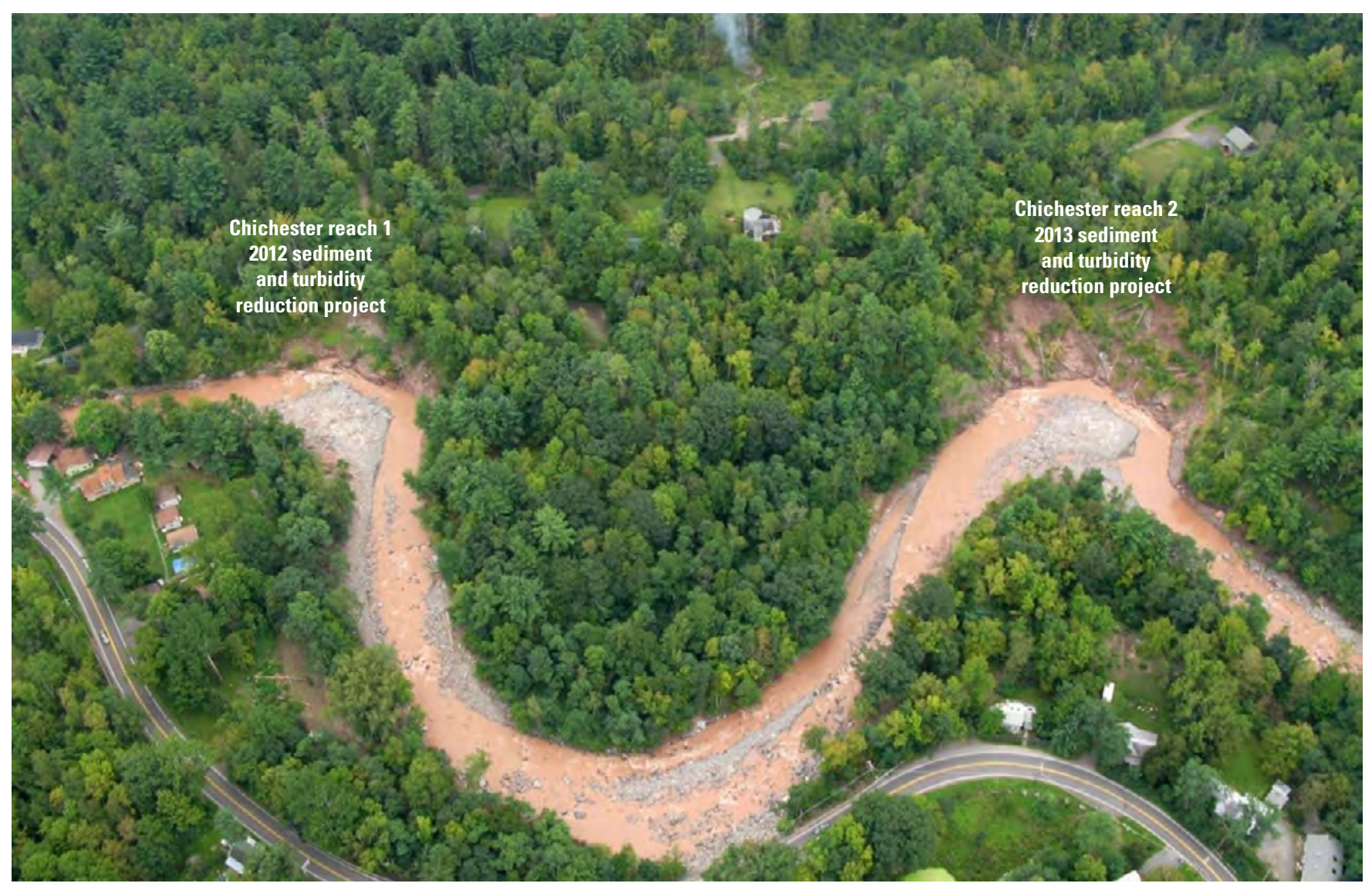

Figure 3. Chichester reaches 1 and 2 of Stony Clove Creek, New York. Note the hillslope failures adjacent to the stream in reaches 1 and 2. Photograph by Wae Danyelle Davis. 
$\boldsymbol{A}$

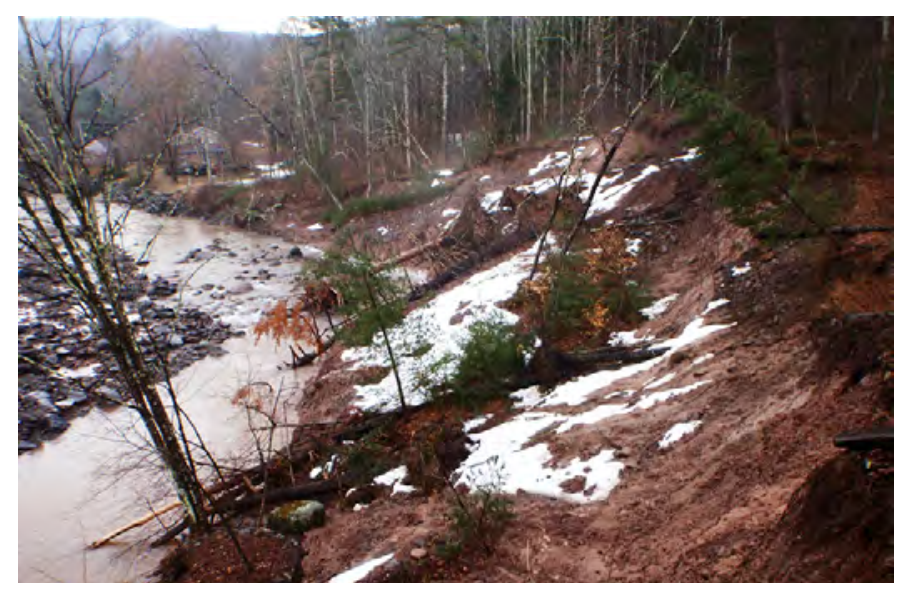

B

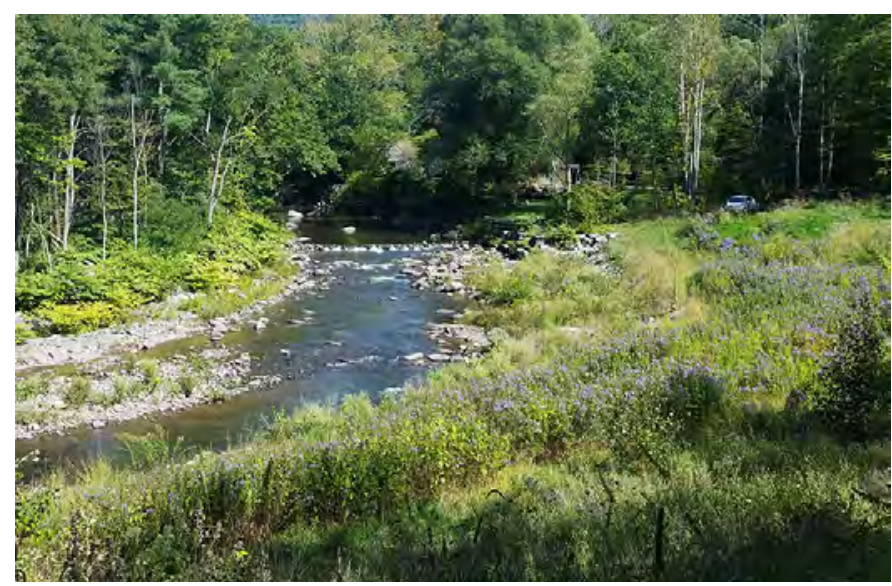

Figure 4. Reach 1 of Stony Clove Creek, New York, $A$, before (March 2011) and B, after (September 2015) the 2012 sediment and turbidity reduction project. Photographs by Wae Danyelle Davis.

\section{Purpose and Scope}

This report describes the results of SSC and turbidity monitoring and the subsequent assessment of four STRPs within the Beaver Kill, Stony Clove Creek, and Warner Creek watersheds, tributaries to the upper Esopus Creek, the main source of water to the Ashokan Reservoir, from October 1, 2010, through September 30, 2014. Statistical results are presented for streamflow conditions, regression analysis of turbidity with suspended-sediment concentration, and concentrations and loads of suspended sediment. Data from the monitoring are available separately through the USGS National Water Information System (U.S. Geological Survey, 2016d).

\section{Study Area}

The Beaver Kill, Stony Clove Creek, and Warner Creek watersheds are within the Esopus Creek watershed upstream from the Ashokan Reservoir in the Catskill Mountains of southeastern New York (fig. 1). The headwaters of these watersheds encompass some of the tallest mountain peaks in the Catskills $(1,067-1,231 \mathrm{~m})$, including the second tallest peak in the Catskills, Hunter Mountain (fig. 1). The watersheds are more than 97 percent forested, much of which is designated as wilderness area or other protected public lands. The bedrock geology consists of repeating sequences of gently dipping Devonian sandstone and shale dissected by streams and glacial ice to form steep slopes in the headwaters (table 2). Surficial geology is characterized by a complex distribution of Pleistocene glacial and proglacial deposits (glacial till, ice contact deposits, glaciofluvial deposits, and glaciolacustrine sediment) that is capped in stream valleys by Holocene alluvium and colluvium (Cadwell and Skiba, 1986). Streambed and streambank exposures of erosion-prone glaciolacustrine deposits composed of finely laminated layers of silt and clay with some sand tend to become chronic sources of suspended sediment even during low to moderate streamflows (table 3; Cornell Cooperative Extension of Ulster County, 2007; Davis and others, 2009).

\section{Methods}

\section{Field Methods}

Water-quality samples and field data were collected by USGS personnel using standard USGS methodology. Stage and turbidity were continuously monitored and water-quality samples were collected at three streamgages-Beaver Kill at Mount Tremper, New York (USGS streamgage 01362487); Stony Clove Creek below Ox Clove at Chichester, New York (USGS streamgage 01362370); and Warner Creek near Chichester, New York (USGS streamgage 01362357; fig. 1).

Stream stage was recorded at 15-minute intervals and stage-discharge relations were developed for each site to derive continuous streamflow (Rantz and others, 1982). Turbidity was measured (Anderson, 2005) every 15 minutes at each location using Forest Technology Systems DTS-12 turbidity sensors at the three streamgage sites. A Hach Surface Scatter 7 (SS7) turbidity monitor also was used to measure turbidity at Stony Clove Creek through September 2012. A comparison of the DTS-12 and Hach SS7 at the Stony Clove Creek streamgage is given in McHale and Siemion (2014). Turbidity sensors were cleaned and the calibration was checked during monthly site visits. Erroneous data because of fouling, sensor obstruction, or ice were removed from the record. Calibration and drift data corrections because of fouling were applied to the turbidity data according to standard methods (Wagner and others, 2006).

Water-quality samples were collected manually and by automated samplers during storms. Manual samples consisted of grab samples collected monthly at each site in 1-liter polypropylene bottles at a single point from a well-mixed part 
Table 2. Watershed characteristics upstream from U.S. Geological Survey streamgages on Beaver Kill, Stony Clove Creek, and Warner Creek, New York.

[USGS, U.S. Geological Survey; ID, identification; m/km, meters per kilometer; km, kilometers; m, meters; km², square kilometers]

\begin{tabular}{|c|c|c|c|}
\hline Watershed characteristic & $\begin{array}{c}\text { Beaver Kill } \\
\text { USGS streamgage ID } 01362487\end{array}$ & $\begin{array}{c}\text { Stony Clove Creek } \\
\text { USGS streamgage ID } 01362370\end{array}$ & $\begin{array}{c}\text { Warner Creek } \\
\text { USGS streamgage ID } 01362357\end{array}$ \\
\hline Average basin slope $(\mathrm{m} / \mathrm{km})$ & 273 & 379 & 350 \\
\hline $10-85$ main channel slope ${ }^{1}(\mathrm{~m} / \mathrm{km})$ & 19.5 & 22.5 & 33.5 \\
\hline Total relief (m) & 967 & 988 & 847 \\
\hline
\end{tabular}

${ }^{1} 10-85$ main channel slope defined as change in elevation between points 10 and 85 percent of length along main channel to the basin divide, divided by the length between the points.

of the channel and by the equal-width depth-integrated (EWI) method according to methods described in Wilde and others (1999). Each site was equipped with a stage-activated water sampler that collected discrete, pumped water samples during storms. The number of samples collected was dependent on the magnitude of the storm. Field quality assurance and quality control were assessed through collection of EWI samples that were collected within 15 minutes of automated and manual samples. The SSCs of concurrently collected samples-EWI, grab, and automatically collected samples-were compared to identify any bias in the results of grab and automatically collected samples.

Discrete water-quality samples were collected during low and moderate-high streamflow periods at sites upstream and downstream from known and suspected sediment sources. Samples were collected in 1-liter polypropylene bottles from well mixed parts of the channel according to methods described in Wilde and others (1999). The results from these samples provided better spatial distribution of suspended sediment along the streams.

\section{Laboratory Methods}

The SSCs were analyzed at the USGS Kentucky Water Science Center Sediment Laboratory. The filtration method was used for samples with perceived concentrations of less than 10,000 milligrams per liter $(\mathrm{mg} / \mathrm{L})$ for sand-sized particles or less than $200 \mathrm{mg} / \mathrm{L}$ for clay-sized particles (Guy, 1969; Shreve and Downs, 2005).

\section{Data Analysis}

Streamflow duration curves were constructed for the study period at the three streamgages to examine how well suspended-sediment sampling covered the range in streamflow conditions that were observed during the study. The streamflow duration curves were created by ranking all daily mean streamflows measured during the period of interest from largest to smallest, calculating the percent of time that each streamflow was equaled or exceeded, and then plotting the daily mean streamflow as a function of the resulting exceedance probability. The exceedance probability was calculated as follows:

$$
P=100 \times\left(\frac{M}{n+1}\right),
$$

where

$P \quad$ is the probability that a given streamflow will be equaled or exceeded (percentage of time),

$M \quad$ is the daily mean streamflow rank, and

$n \quad$ is the number of days in the record.

Concurrent measurements of turbidity and SSC were used to develop turbidity-SSC regression equations for each

Table 3. Stream feature inventory results for Beaver Kill, Stony Clove Creek, and Warner Creek, New York.

[SFI, stream feature inventory; m, meters; Stream feature inventory results provided by the Ashokan Watershed Stream Management Program.]

\begin{tabular}{lccccc}
\hline \multicolumn{1}{c}{ Stream } & Date of SFI & $\begin{array}{c}\text { Length of } \\
\text { inventoried channel } \\
(\mathbf{m})\end{array}$ & $\begin{array}{c}\text { Length of } \\
\text { bank erosion } \\
(\mathbf{m})\end{array}$ & $\begin{array}{c}\text { Length of bank erosion in contact } \\
\text { with fine sediment source } \\
(\mathbf{m})\end{array}$ & $\begin{array}{c}\text { Dominant fine } \\
\text { sediment geology }\end{array}$ \\
\hline Beaver Kill & 2009 & 15,342 & 3,989 & 1,117 & Till \\
Stony Clove Creek & 2013 & 16,599 & 1,826 & 986 & Lacustrine \\
Warner Creek & 2010 & 15,284 & 1,681 & 286 & Lacustrine \\
\hline
\end{tabular}


site (Rasmussen and others, 2009). An analysis of covariance (ANCOVA) was used to test for changes in the turbidity-SSC relation during the study period. The SSC was used as the dependent variable, and turbidity was the independent variable. A STRP factor, which separated the dataset into periods before and after construction of the STRP, was used as the ANCOVA analysis factor. A significant difference in the STRP factor before and after STRP construction indicated a change in the relation between turbidity and SSC.

The turbidity-SSC regression equations were applied to 15-minute in-situ turbidity values to calculate SSC at a 15-minute time step. The 15-minute SSC and 15-minute streamflow data were used in the USGS Graphical Constituent Loading and Analysis System (Koltun and others, 2006) to calculate daily mean SSCs and daily loads for each site. For days when 15-minute turbidity values were not available, the relation between daily mean streamflow and daily mean SSC was used to estimate daily mean SSC (table 4). This relation was developed by using daily mean streamflow as the independent variable and daily mean SSC (calculated from the turbidity-SSC relation) as the dependent variable. Daily suspended-sediment loads were then calculated by multiplying the daily mean SSC by the daily mean streamflow and converting the result to short tons per day.

The relation between streamflow and SSC was analyzed using an ANCOVA to account for differences in streamflow between the before and after STRP periods. Daily mean SSC was used as the dependent variable, and daily mean streamflow was used as the independent variable. The STRP factor, as previously described, was used as the ANCOVA analysis factor. A significant difference in the STRP factor before and after STRP construction indicated a change in the relation between daily mean streamflow and SSC. The nonparametric Wilcoxon rank sum test (Helsel and Hirsch, 2002) was used to determine if significant (alpha equals 0.05) differences in SSC were measured between the before and after
STRP construction periods at each of the three streamgages at similar streamflow and to determine if significant differences in streamflow existed between periods. This analysis targeted 10-percentile ranges in streamflow to reflect low, moderate, and high streamflows. Low streamflows were those that were equaled or exceeded 90 percent of the time (Q90). Moderate streamflows were those that were equaled or exceeded between 45 and 55 percent of the time (Q45 to Q55). High streamflows were those that were equaled or exceeded less than 10 percent of the time (Q10).

\section{Results and Discussion}

Daily mean SSCs and loads were analyzed to determine the effects of the STRPs on SSC and loads in the Stony Clove Creek and Warner Creek and for reference in the untreated Beaver Kill. Daily mean SSCs and loads are directly affected by changes in streamflow; thus, any differences in streamflow between the before and after STRP construction periods must be accounted for. Daily mean streamflow, daily mean SSC, and daily load data are available for the Beaver Kill at Mount Tremper, New York (USGS streamgage 01362487; U.S. Geological Survey, 2016a), for Stony Clove Creek below Ox Clove at Chichester, New York (USGS streamgage 01362370; U.S. Geological Survey, 2016b), and for Warner Creek near Chichester, New York (USGS streamgage 01362357; U.S. Geological Survey, 2016c) through the USGS National Water Information System (U.S. Geological Survey, 2016d).

\section{Streamflow Conditions}

High streamflow events were less frequent in the Stony Clove Creek watershed from 2012 to 2014 than from 2010 to 2011 (fig. 5) when numerous high streamflows were recorded,

Table 4. Details of regressions of daily mean suspended-sediment concentrations on daily mean streamflows.

$\left[r^{2}\right.$, coefficient of determination; $\mathrm{n}$, number of samples used in regression; $\%$ est load, percentage of annual suspended sediment load estimated regression equation; STRP, sediment and turbidity reduction project; <, less than]

\begin{tabular}{|c|c|c|c|c|c|c|}
\hline \multirow{2}{*}{ Streamgage } & \multicolumn{2}{|c|}{$\begin{array}{l}\text { Range in daily mean streamflow, } \\
\text { in cubic feet per second }\end{array}$} & \multirow{2}{*}{ Equation } & \multirow{2}{*}{$r^{2}$} & \multirow{2}{*}{$\mathbf{n}$} & \multirow{2}{*}{$\begin{array}{l}\% \text { est } \\
\text { load }\end{array}$} \\
\hline & $\begin{array}{l}\text { During study } \\
\text { period }\end{array}$ & $\begin{array}{l}\text { Accounted for by samples } \\
\text { during study period }\end{array}$ & & & & \\
\hline Beaver Kill at Mount Tremper, New York & $2.3-1,642$ & $2.3-1,400$ & $1.14 \times$ streamflow -0.96 & 0.70 & 989 & 12 \\
\hline $\begin{array}{l}\text { Stony Clove Creek below Ox Clove at } \\
\text { Chichester, New York, before STRP }\end{array}$ & $2.3-5,189$ & $2.3-3,347$ & $0.58 \times$ streamflow +0.78 & 0.28 & 1,142 & 4 \\
\hline $\begin{array}{l}\text { Stony Clove Creek below Ox Clove at } \\
\text { Chichester, New York, after } 2012 \text { STRP }\end{array}$ & $2.3-992$ & $2.3-992$ & $0.88 \times$ streamflow -23.3 & 0.46 & 1,296 & $<1$ \\
\hline $\begin{array}{l}\text { Warner Creek near Chichester, New York, } \\
\text { before } 2013 \text { STRP }\end{array}$ & $1.6-323$ & $1.6-323$ & $0.79 \times$ streamflow +0.21 & 0.73 & 342 & $<1$ \\
\hline $\begin{array}{l}\text { Warner Creek near Chichester, New York, } \\
\text { after } 2013 \text { STRP }\end{array}$ & $1.5-297$ & $1.5-297$ & $0.34 \times$ streamflow -1.46 & 0.68 & 362 & $<1$ \\
\hline
\end{tabular}


including the period of record peak streamflow on August 28, 2011. The lower streamflow conditions during 2012-14 are important to note when stating the effectiveness of the STRPs. In general, SSCs will be greater during periods of higher streamflows than of lower streamflows. Statistically significant differences in streamflow were observed in Stony Clove Creek and Warner Creek between the pre- and post-STRP periods, which precluded direct comparisons of SSC between the two periods (fig. 6). Instead, SSCs were compared within similar streamflow classes (less than Q90, Q45 to Q55, and greater than Q10) for the pre- and post-STRP periods. Changes in the relation between SSCs and streamflow during the pre- and post-STRP periods also were examined. Discrete samples were collected throughout the range of daily mean streamflow observed during the study period at the Stony Clove Creek streamgage (fig. 7).

\section{Turbidity-Suspended-Sediment Concentration Regressions}

The period of record for the turbidity values was from December 1, 2010, through September 30, 2014, for the Beaver Kill and Stony Clove Creek streamgages and from June 12, 2012, through September 30, 2014, for the Warner
Creek streamgage. The range in turbidity is well represented by the samples collected at the Beaver Kill and Stony Clove Creek streamgages, but only the lower 50 percent of the range in turbidity is represented by the samples collected at Warner Creek streamgage (table 5). However, of the more than 81,000 turbidity values recorded at 15 -minute intervals during the study period at the Warner Creek streamgage, only 28 were outside the range accounted for by the SSC samples collected and were recorded on four individual days.

Regression equations between turbidity and SSC were developed for each streamgage so that 15-minute SSC could be predicted from the 15-minute turbidity values measured by the SS7 and DTS-12 turbidity sensors (fig. 8). The numbers of concurrent SSC and turbidity measurements at each streamgage were 73 at the Beaver Kill streamgage, 36 at the Stony Clove Creek streamgage for the SS7, 71 at the Stony Clove Creek streamgage for the DTS-12, and 81 at the Warner Creek streamgage (appendix 1). The measurements included between 5 and 7 quality assurance and quality control samples at each streamgage. Streamflow was generally low (exceeded less than 50 percent of the time) when quality assurance and quality control samples were collected because site conditions precluded collection of EWI samples at high streamflow at the Beaver Kill and Warner Creek streamgages. At the Beaver Kill streamgage, the bridge structure prevented the use of

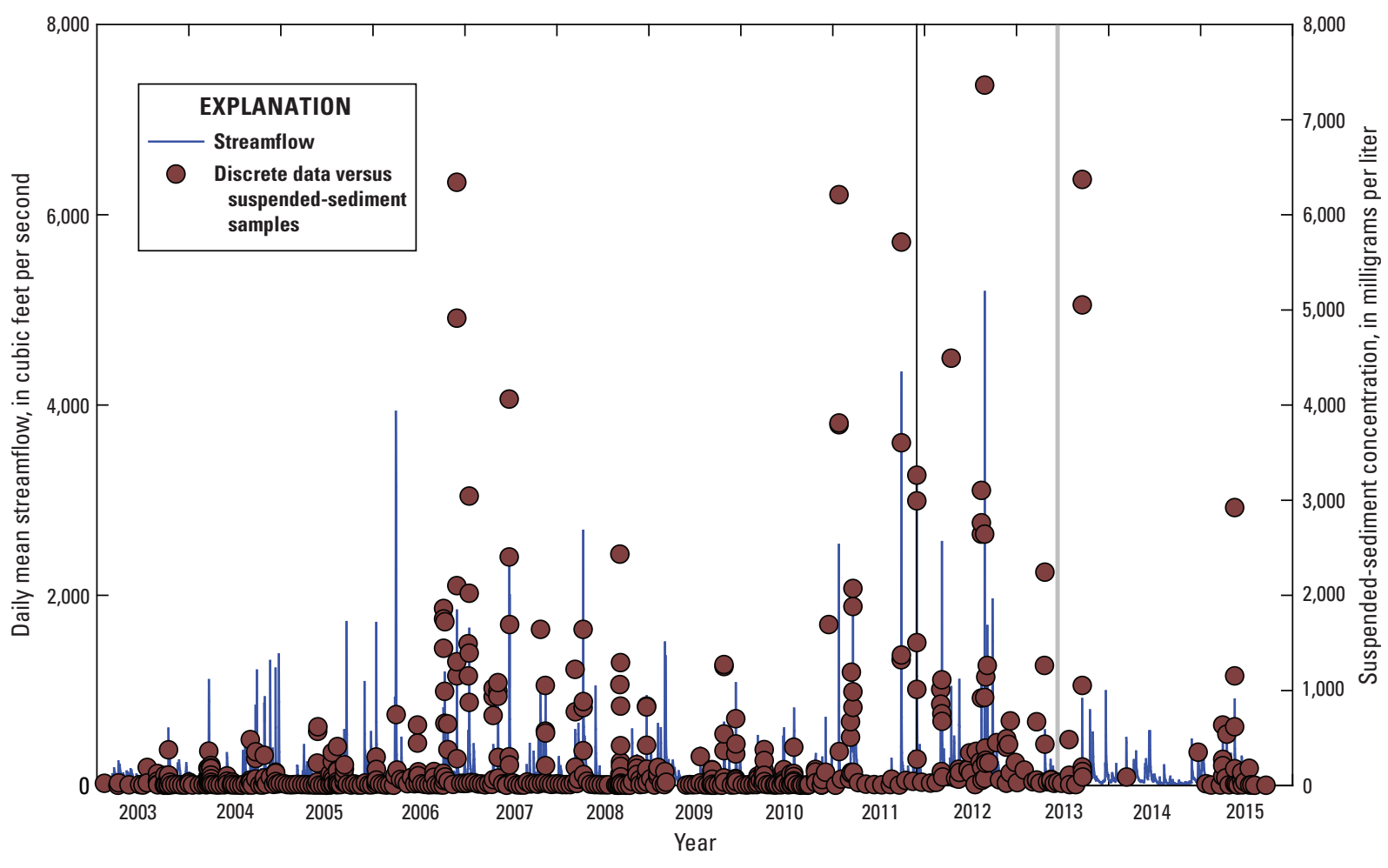

Figure 5. Daily mean streamflow and suspended-sediment samples for the period of record at Stony Clove Creek below 0x Clove at Chichester, New York. Beginning of study period is indicated by black line for the Beaver Kill at Mount Tremper, New York, and Stony Clove Creek below 0x Clove at Chichester, New York, streamgages and by grey line for the Warner Creek near Chichester, New York, streamgage. 

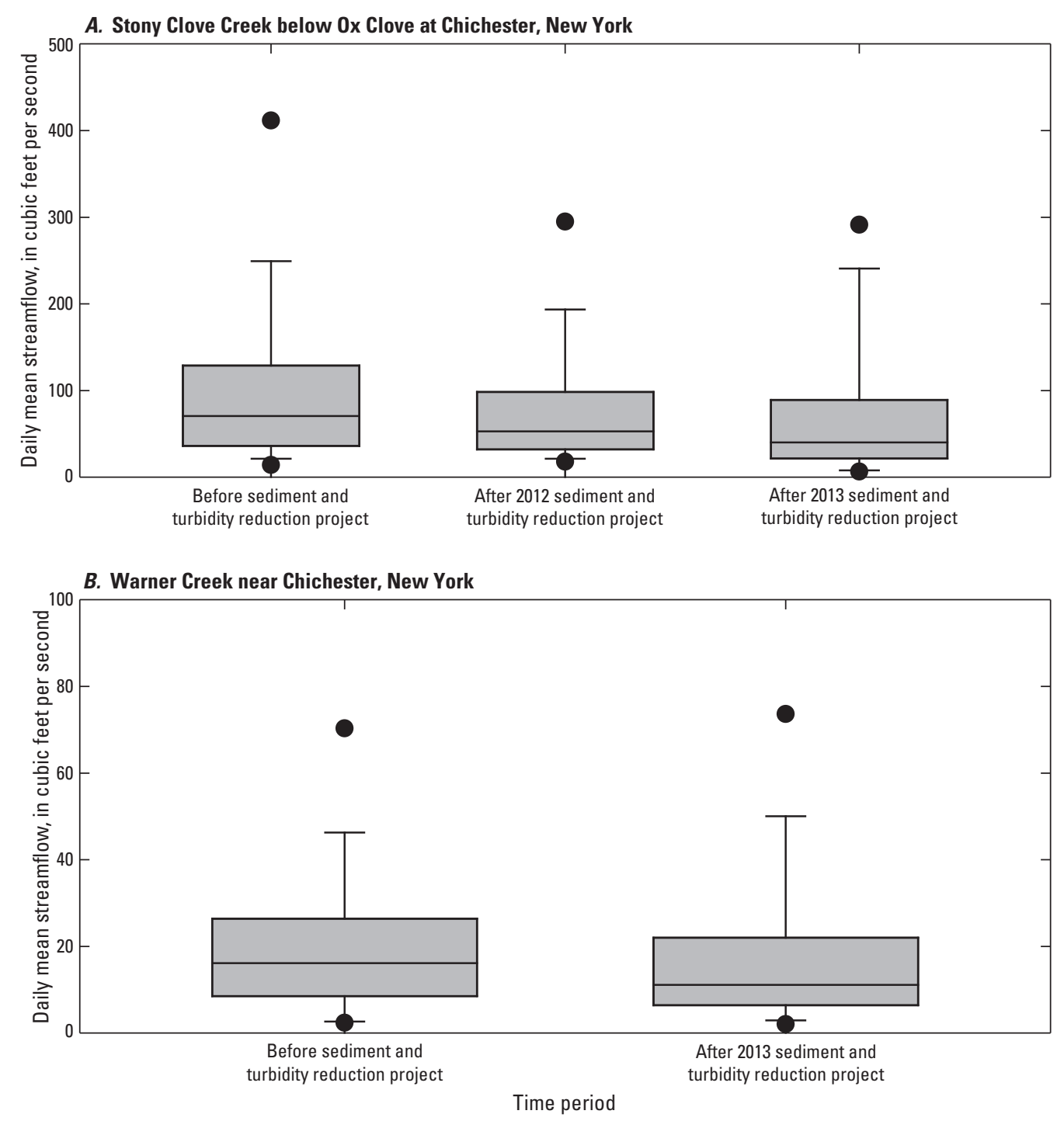

Figure 6. Daily mean streamflow before and after sediment and turbidity reduction projects at the $A$, Stony Clove Creek below 0x Clove at Chichester, New York, and B, Warner Creek near Chichester, New York, streamgages.

a bridge crane, and at the Warner Creek streamgage, there was no bridge to sample from. Installation of cableways was beyond the scope of this project. Sediment samples obtained at a single point of streamflow within a cross section may not be representative of the mean sediment concentration (Edwards and Glysson, 1999). However, comparison of the automated storm, EWI, and grab sample SSC (fig. 8) indicated no consistent cross-channel differences and no bias from any of the sampling methods.

The ordinary least squares relation between SSC and turbidity displayed an increasing variance in SSC with increasing turbidity, which resulted in the need to log transform the variables. Spearman's rho was computed to check for serial correlation, that is, the dependence or correlation in time sequence between residuals (Helsel and Hirsch, 2002).
Serial correlation likely was caused by the high frequency of sample collection during runoff. The time between samples was calculated if serial correlation was detected. Samples with the shortest time between sample collections were then removed from the model dataset until serial correlation was no longer detected. The subsampling resulted in 64 concurrent measurements used in the Beaver Kill model, 63 in the Stony Clove Creek model, and 62 in the Warner Creek model. The Duan bias correction factor was computed to correct for bias introduced by the retransformation of the model parameters from log space (Duan, 1983). The turbidity-SSC models were consistent throughout the study period, and no changes in the relations were observed at the three streamgages pre- and post-STRP. 
A. Beaver Kill at Mount Tremper, New York

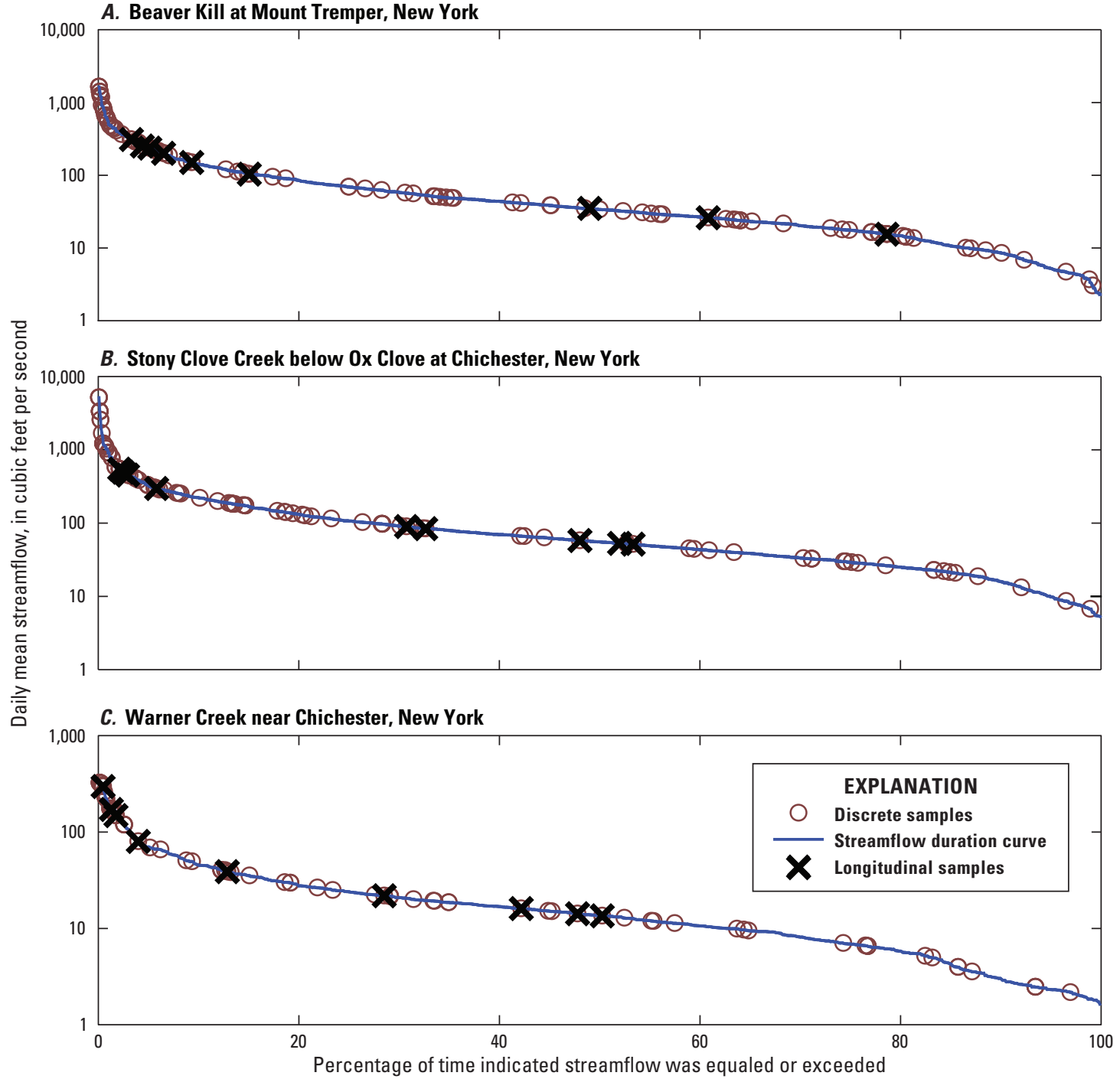

Figure 7. Study period streamflow duration curves for $A$, Beaver Kill, $B$, Stony Clove Creek, and $C$, Warner Creek, New York, showing daily mean streamflow at which discrete samples were collected, and daily mean streamflow at which longitudinal sampling was conducted.

Table 5. Details of discrete turbidity-suspended-sediment concentration regressions.

[FNU, formazin nephelometric units; BCF, bias correction factor; $r^{2}$, coefficient of determination; $\mathrm{n}$, number of samples used in regression; period of record December 1, 2010, to September 30, 2014, for Beaver Kill and Stony Clove Creek streamgages and June 12, 2012, to September 30, 2014, for Warner Creek streamgage]

\begin{tabular}{|c|c|c|c|c|c|c|}
\hline \multirow[b]{2}{*}{ Streamgage } & \multicolumn{2}{|c|}{ Range in turbidity, in FNU } & \multirow[b]{2}{*}{ Equation } & \multirow[b]{2}{*}{ Duan BCF } & \multirow[b]{2}{*}{$r^{2}$} & \multirow[b]{2}{*}{$\mathbf{n}$} \\
\hline & $\begin{array}{l}\text { During period } \\
\text { of record }\end{array}$ & $\begin{array}{l}\text { Accounted for by samples } \\
\text { during period of record }\end{array}$ & & & & \\
\hline $\begin{array}{l}\text { Stony Clove Creek below Ox Clove at } \\
\text { Chichester, New York }\end{array}$ & $0-1,860$ & $3.2-1,840$ & $1.29 *$ Turbidity $^{-0.587}$ & 1.082 & 0.93 & 63 \\
\hline
\end{tabular}


A. Beaver Kill at Mount Tremper, New York

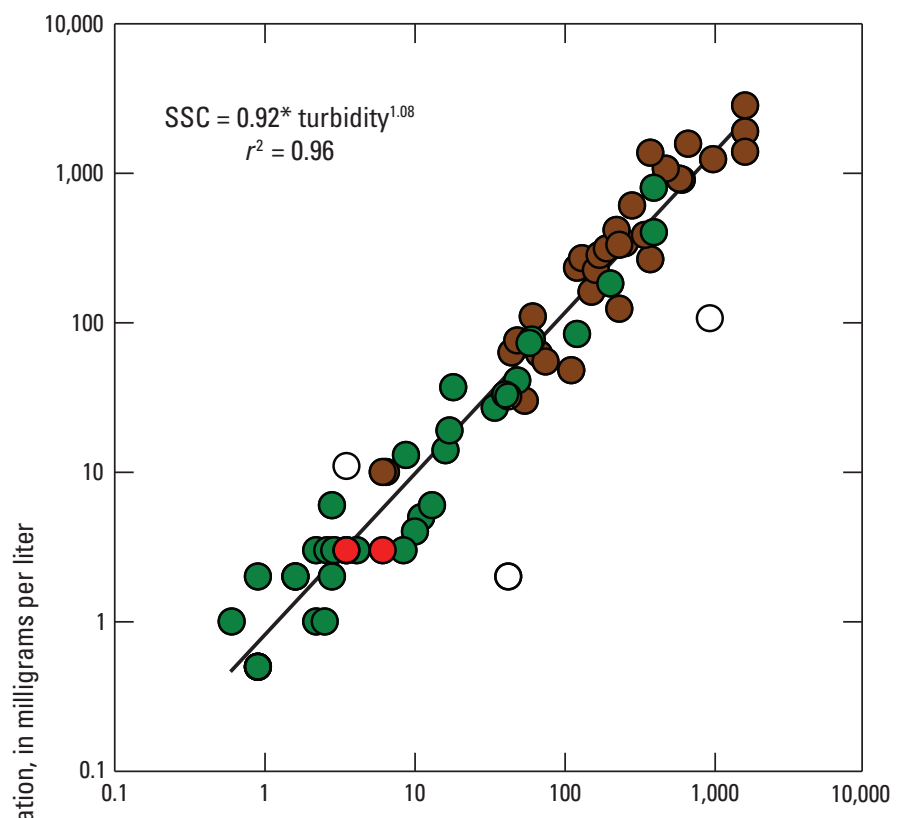

C. Stony Clove Creek below 0x Clove at Chichester, New York (Hach Surface Scatter 7 turbidity probe)

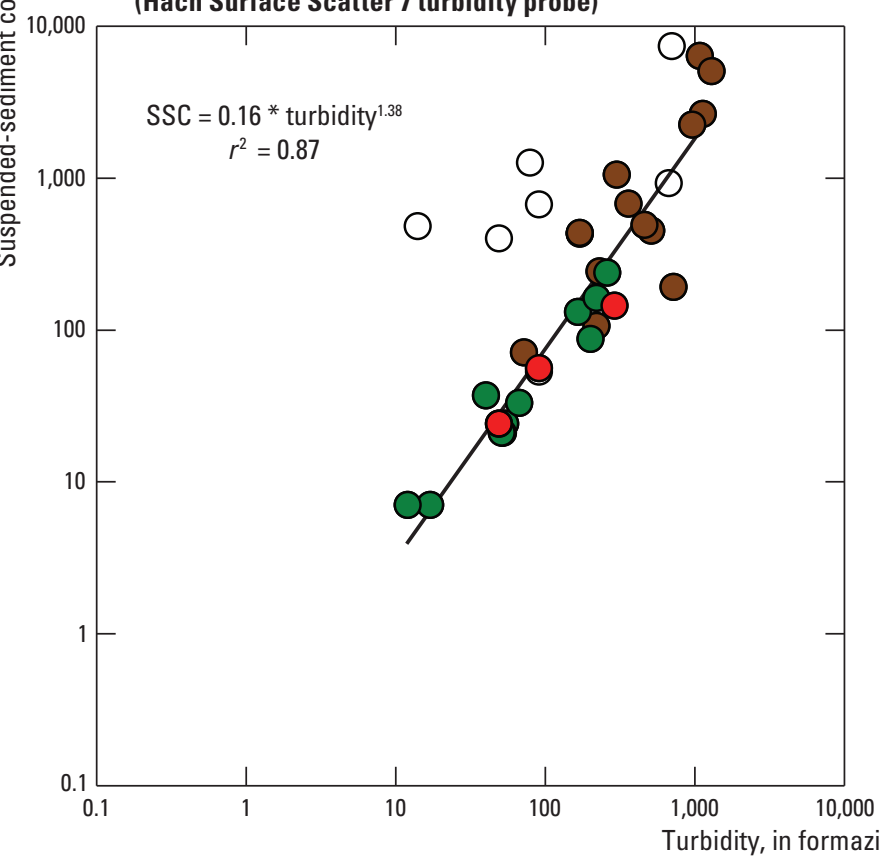

B. Stony Clove Creek below 0x Clove at Chichester, New York (DTS-12)

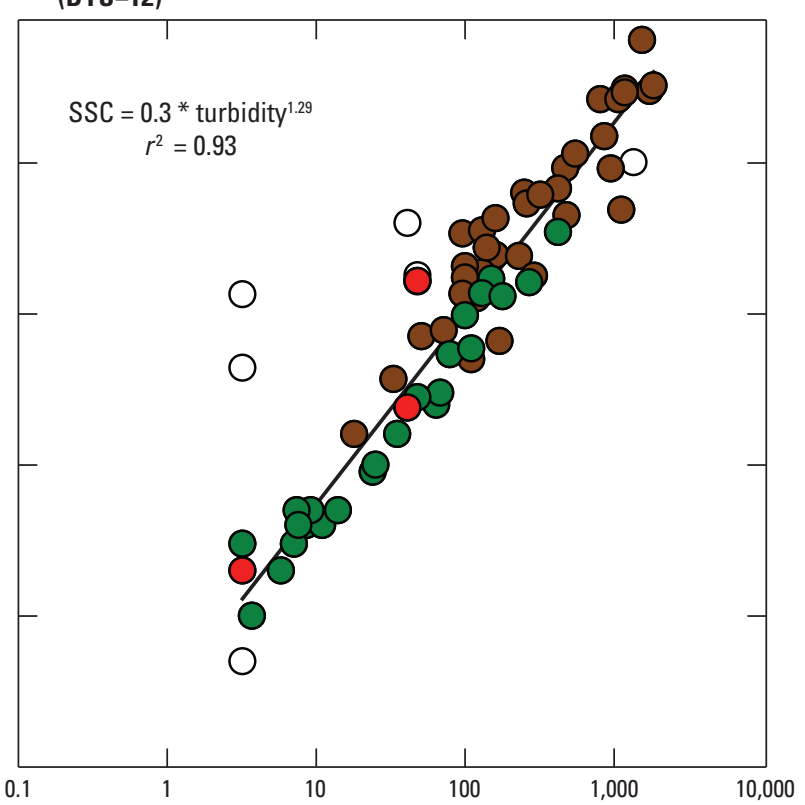

D. Warner Creek near Chichester, New York

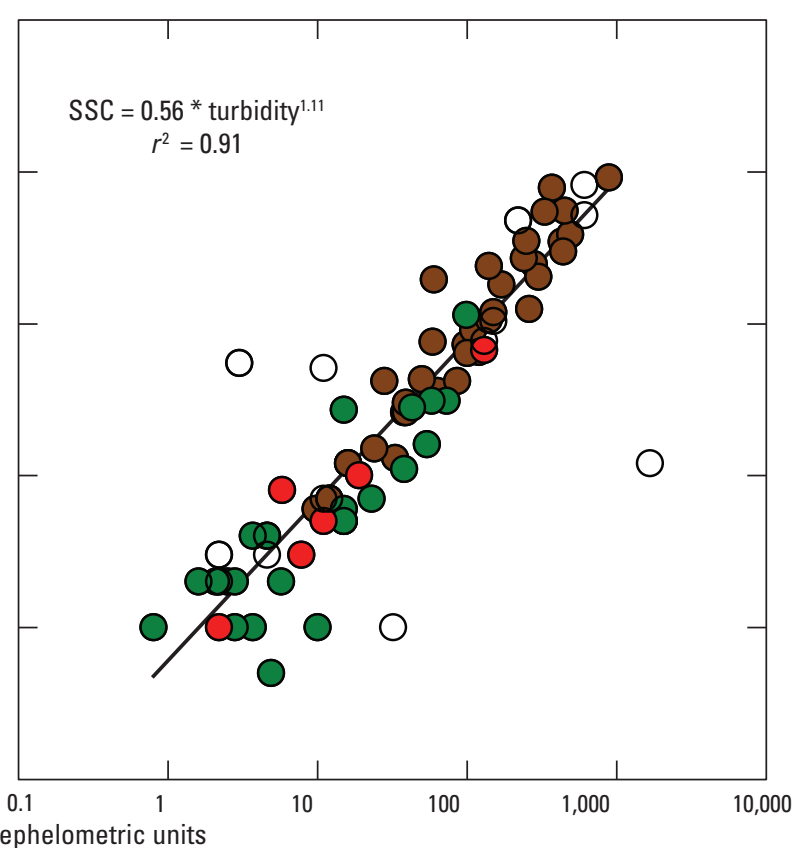

\section{EXPLANATION}

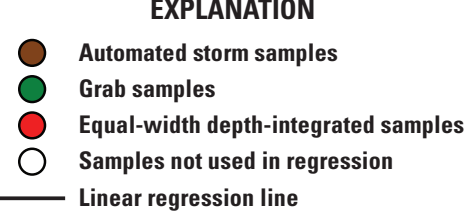

Figure 8. Relations between in-situ turbidity and suspended-sediment concentration (SSC) at the A, Beaver Kill at Mount Tremper, New York, B, Stony Clove Creek below 0x Clove at Chichester, New York (DTS-12 turbidity sensor), C, Stony Clove Creek below 0x Clove at Chichester, New York (Hach Surface Scatter 7 turbidity sensor), and D, Warner Creek near Chichester, New York, streamgages. Turbidity to SSC relation statistics are listed in table 3. The samples included in the regression models are a subset of the available data; some samples were not included because of serial correlation. Equations shown are retransformed back from log space. 


\section{Suspended-Sediment Concentrations and Loads}

The error associated with calculation of suspendedsediment loads is generally a function of the errors associated with the streamflow record and the turbidity-SSC regression equation. The USGS streamflow records are assigned a qualitative error estimate of excellent, good, fair, or poor. The streamflow records used for load calculation at the stream gages were rated fair (within 15 percent of the true streamflow about 95 percent of the time) for days when streamflows were computed from a station's stage-discharge relation and poor (greater than 15 percent different from the true streamflow) for days when streamflows were estimated. The turbidity-SSC regression equations explained 90 to 96 percent of the variation in the relation between turbidity and SSC, and the daily mean streamflow-SSC regression equations explained 28 to 73 percent of the variation in the relation between daily mean streamflow and SSC. Although the daily mean streamflowSSC regression equation coefficient of determinations were low in some cases, the suspended-sediment loads computed from these equations represented a small percentage of the annual loads.

Annual suspended-sediment loads representing the total export of sediment from the study watersheds were apportioned into construction and nonconstruction periods (fig. 9). Suspended-sediment loads in Stony Clove Creek generally were greater than those in Beaver Kill by a factor of 6 to 10 during water years 2010-13. (Water year is defined as the 12-month period October 1, for any given year through September 30 , of the following year. The water year is designated by the calendar year in which it ends.) These results were similar to results reported by McHale and Siemion (2014). After the completion of the STRPs in the Stony Clove Creek watershed, the difference in loads between Beaver Kill and Stony Clove Creek was reduced to less than a factor of 2 during water year 2014. Warner Creek contributed 4 percent of the suspended-sediment load in Stony Clove Creek during water year 2013, but accounted for 10 percent of the load during water year 2014.

Daily mean SSCs were calculated using the relation between SSC in discrete samples and concurrent in-situ turbidity values. Daily mean SSCs were only calculated for days when in-situ turbidity values were available; therefore, some high streamflow days when the in-situ turbidity probe was damaged were not represented in the turbidity-SSC relation. Daily mean SSCs were used to investigate changes in SSC as a result of the STRPs, as indicated by a change in the relation between daily mean SSC and daily mean streamflow. Differences in the range in daily mean SSC between the preand post-STRP periods could be determined by examining differences in the relation between daily mean SSC and daily mean streamflow.

The daily mean SSC at the Beaver Kill stream gage served as a control in the sense that no STRPs were constructed in Beaver Kill during the study period. Daily mean SSCs were greater during 2010-11 than during 2012-14, likely because of the higher streamflow during 2010-2011 (fig. 10A). Nonetheless, the relation between daily mean SSC and daily mean streamflow at the Beaver Kill stream gage did not change during the study period (fig. 10B). Therefore, we assumed the constancy of the SSC-streamflow relation at Stony Clove Creek and Warner Creek and attributed changes in the relation at these sites to the effects of the STRPs.

Daily mean SSCs at the Stony Clove Creek stream gage were greater during 2010-11 than during 2012-14 in part because of the greater streamflows during the period 20102011 (fig. 11A). Damage to the in-situ turbidity probe during the pre-STRP period precluded calculation of daily mean SSCs for some days on which high streamflow was recorded, including the period of record streamflow on August 28, 2011. The relation between daily mean streamflow and daily mean SSC changed among the pre-STRP, post-2012 STRP, and post-2013 STRP periods. After the 2012 and 2013 STRPs were completed, the daily mean SSC significantly decreased for a given daily mean streamflow (fig. 11B). Because of the differences in streamflow during the study period, tests for differences in daily mean SSC between periods were conducted on three streamflow classes in addition to the daily SSC-daily streamflow analysis. High streamflows are those that are equaled or exceeded less than 10 percent of the time (Q10). Moderate streamflows are those that are equaled or exceeded between 45 and 55 percent of the time (Q45 to Q55). Low streamflows are those that are equaled or exceeded 90 percent of the time (Q90; fig. 12C). Comparison of SSC by streamflow class eliminated the problem of significant differences in the streamflow among the pre- and post-STRP periods. Declines in daily mean SSCs were significant for high, moderate, and low flows among the three sampling periods (before the STRP, between the 2012 and 2013 STRPs, and after the 2013 STRP; fig. $12 A-C$ ). The STRPs completed in the Stony Clove Creek watershed during the study period decreased the median of the daily mean SSCs by nearly $300 \mathrm{mg} / \mathrm{L}$ at high streamflow, about $80 \mathrm{mg} / \mathrm{L}$ at moderate streamflow, and about $40 \mathrm{mg} / \mathrm{L}$ at low streamflow (fig. $12 A-C$ ).

Similar to the results for the Beaver Kill and Stony Clove Creek streamgages, daily mean SSCs at the Warner Creek streamgage were greater during 2012 than 2014 because of the greater streamflows during 2012 (fig. 13A). The relation between daily mean SSC and daily mean streamflow at the Warner Creek streamgage changed after the 2013 STRP was completed (fig. 13B). Daily mean SSC significantly decreased for a given daily mean streamflow. Because streamflow at the Warner Creek station was significantly greater before the STRPs than after, flow classes were tested in the same manner as described for the Stony Clove Creek streamgage, and the same definitions were used for high, moderate, and low flow (fig. 14A-C). Daily mean SSCs at the Warner Creek streamgage significantly decreased at high flow, moderate flow, and low flow after the 2013 STRP was completed compared with before the STRP. The STRP completed in the Warner Creek watershed decreased the median of daily mean 
A. Beaver Kill at Mount Tremper, New York

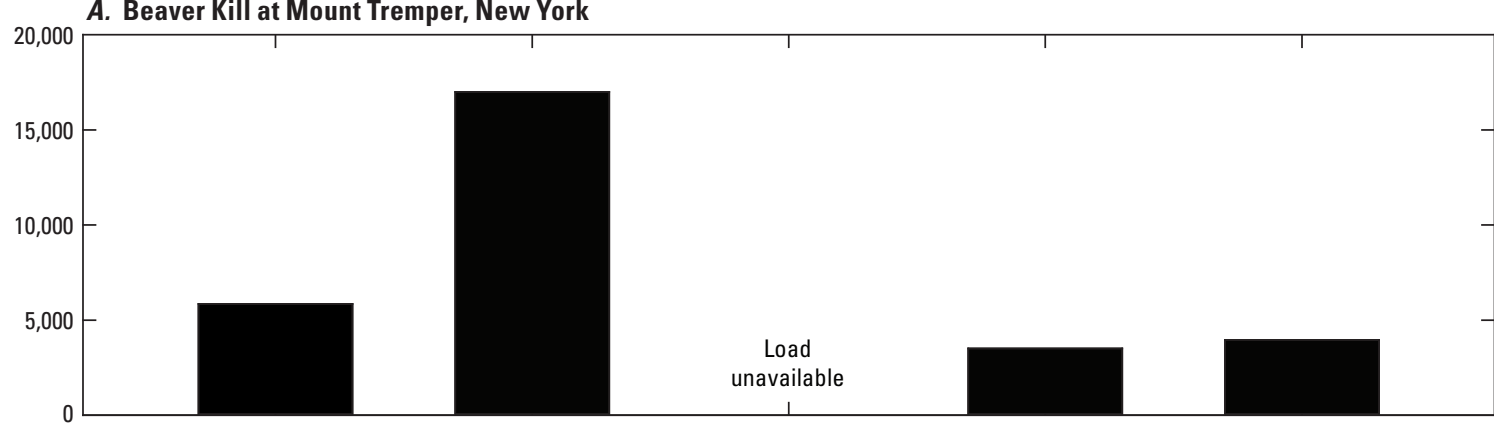

B. Stony Clove Creek below 0x Clove at Chichester, New York

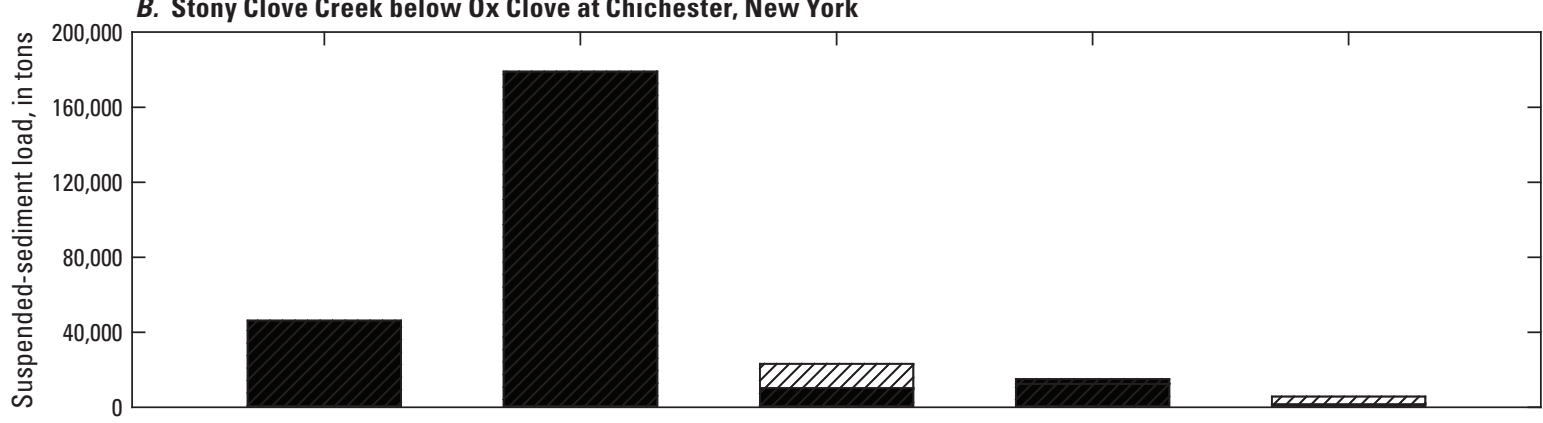

C. Warner Creek near Chichester, New York

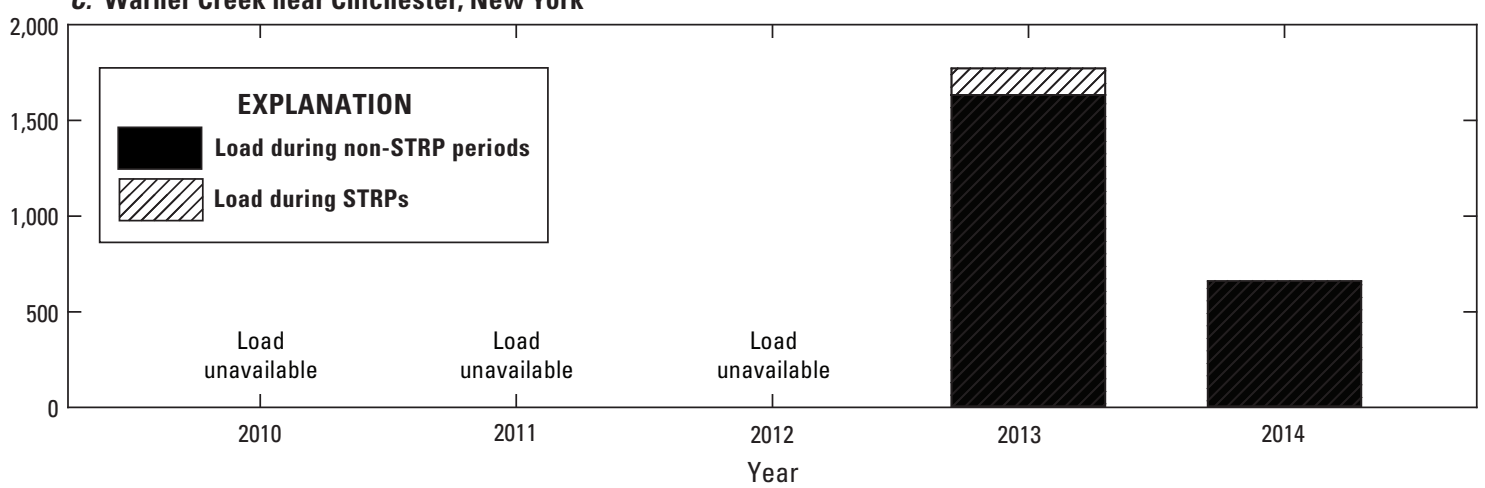

Figure 9. Suspended-sediment loads during sediment and turbidity reduction projects (STRP) and during non-STRP periods for the $A$, Beaver Kill at Mount Tremper, New York, $B$, Stony Clove Creek below 0x Clove at Chichester, New York, $C$, Warner Creek near Chichester, New York, streamgages. Annual (October 1 through September 30) loads equal the sum of the two boxes.

SSC by nearly $40 \mathrm{mg} / \mathrm{L}$ at high streamflow, $10 \mathrm{mg} / \mathrm{L}$ at moderate streamflow, and $4 \mathrm{mg} / \mathrm{L}$ at low streamflow (fig. $14 A-B$ ).

\section{Longitudinal Sampling Results}

Longitudinal sampling provided a snapshot of SSCs along each stream channel at discrete points in time. Samples were collected five times at high streamflows, generally those that are equaled or exceeded less than 20 percent of the time (Q20; fig. 6) and six times at moderate to low streamflows, generally those that are equaled or exceeded 50 percent of the time (Q50; fig. 6). Although the small sample sizes preclude a quantitative analysis, the sampling data do provide insight into which stream reaches are producing the highest SSCs.

The minimum, mean, and maximum SSCs for high and low streamflow sampling (figs. 15-17) indicate that the mean SSCs were less than $1 \mathrm{mg} / \mathrm{L}$ during low streamflows and less than $4 \mathrm{mg} / \mathrm{L}$ during high streamflow in the 100 percent forested headwaters of the Beaver Kill (BKL08; fig. 15A-B). During high streamflows at the next downstream site, mean SSCs were $81 \mathrm{mg} / \mathrm{L}$, and at sites further downstream mean SSCs were between 54 and $68 \mathrm{mg} / \mathrm{L}$ (fig. 15A). Mean SSCs during low streamflow at sites downstream from the headwaters were $4-8 \mathrm{mg} / \mathrm{L}$ (fig. 15B). The sampling results suggest that the stream reach between sites BKL07 and BKL08 is the 

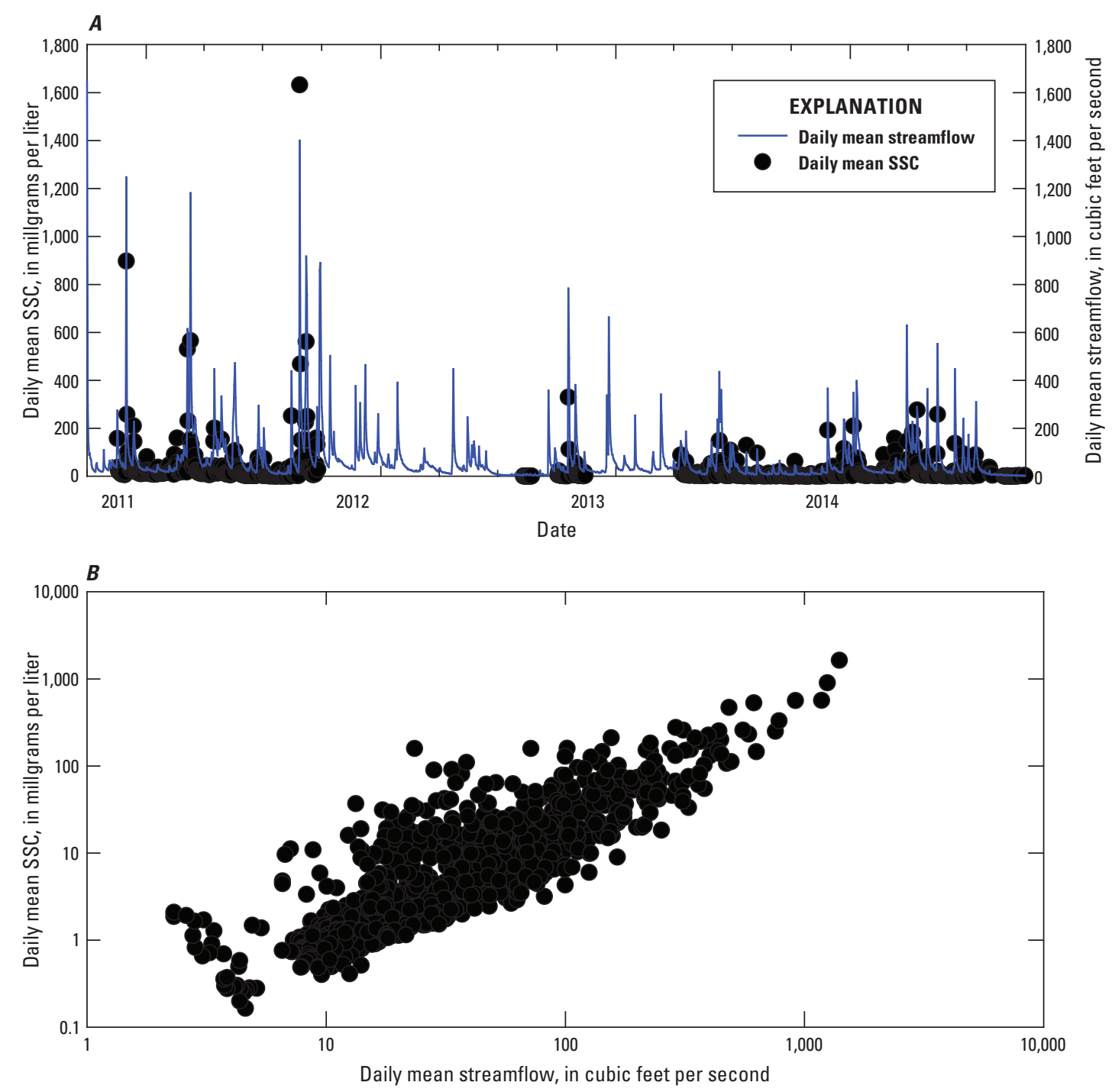

Figure 10. A, daily mean suspended-sediment concentration (SSC) and streamflow and $B$, daily mean SSC as a function of daily mean streamflow daily mean and streamflow at the Beaver Kill at Mount Tremper, New York, streamgage.

largest source of suspended sediment to the Beaver Kill. The channel is in contact with large, actively eroding hillslope failures in that stream reach, although eroding banks and fine sediment exposures are present throughout the length of the Beaver Kill channel downstream from the headwaters (fig. 15; Ashokan Watershed Stream Management Program, 2015). The sampling results indicate that the Beaver Kill is disconnected from sediment sources during low streamflows.

The headwater Hollow Tree Brook site (HT0001; fig. 16) was used to represent background SSCs in the Stony Clove Creek watershed. Mean SSCs during sampling at the HT0001 site were $3 \mathrm{mg} / \mathrm{L}$ during high streamflows and less than $1 \mathrm{mg} / \mathrm{L}$ during low streamflows (fig. 16A-B). Between sites HT0001 and HTL01, mean SSC increased to $19 \mathrm{mg} / \mathrm{L}$ during high streamflows and $4.5 \mathrm{mg} / \mathrm{L}$ during low streamflows. This increase in SSC indicates that a source of suspended sediment exists in the lower reaches of Hollow Tree Brook during high streamflows. The most upstream sampling site along the main stem of Stony Clove Creek (PHL07; fig. 16) was not a headwater site, but the site does serve as a reference for the downstream sampling points. Note, however, that sites PHL07 and PHL06 were established after the project was underway and, therefore, were not sampled as frequently as the other sites. Mean SSCs at the two upstream Stony Clove Creek sites were $15 \mathrm{mg} / \mathrm{L}$ during high streamflows and less than $2 \mathrm{mg} / \mathrm{L}$ during low streamflows.

During high streamflows, mean SSCs in Stony Clove Creek watershed increased steadily downstream from 37 

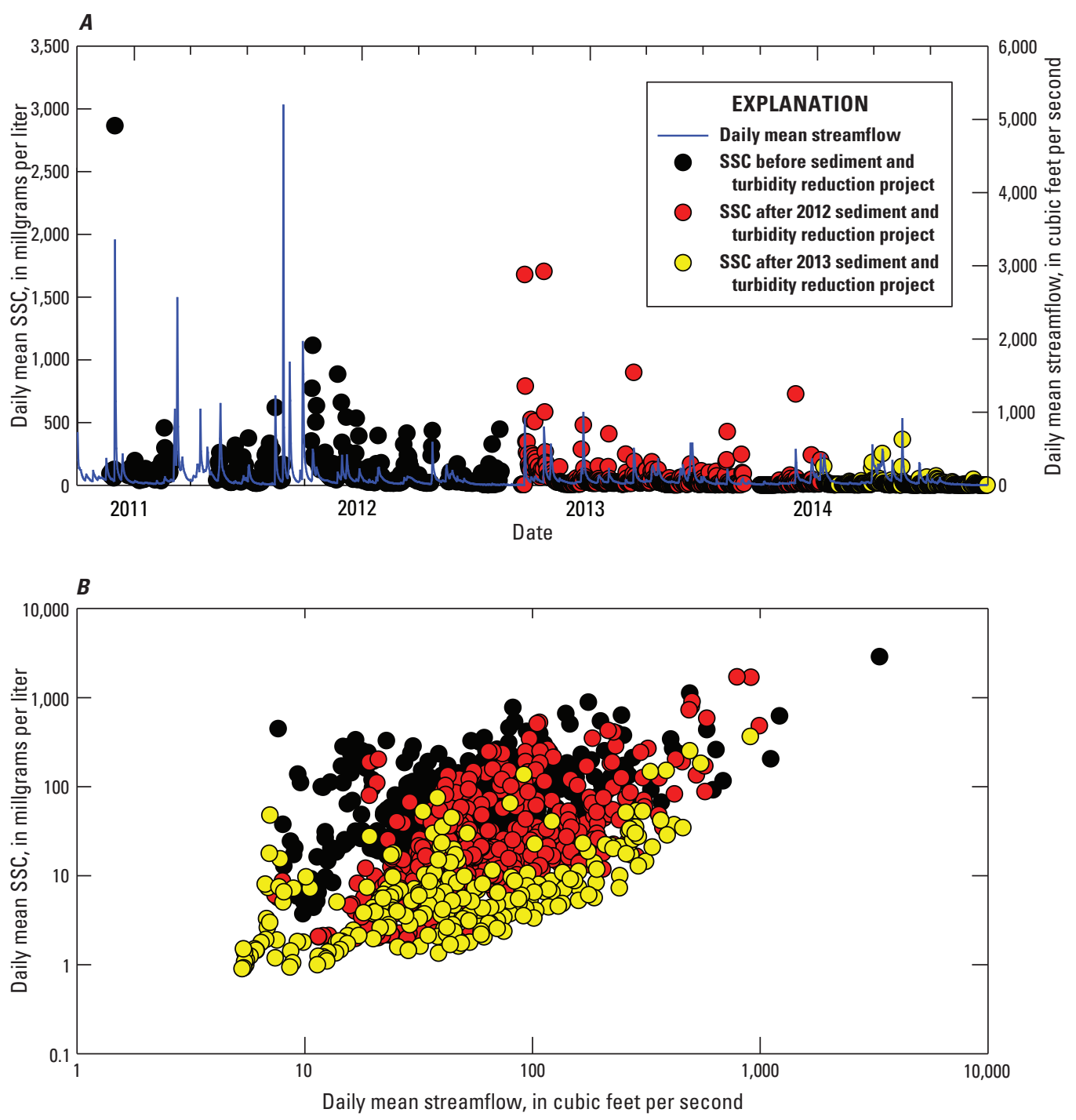

Figure 11. $A$, daily mean suspended-sediment concentration (SSC) and streamflow and $B$, daily mean SSC as a function of daily mean streamflow before and after the sediment and turbidity reduction projects at the Stony Clove Creek below 0x Clove at Chichester, New York, streamgage.

$\mathrm{mg} / \mathrm{L}$ at site PHL05 to $45 \mathrm{mg} / \mathrm{L}$ at site PHL04 and to $61 \mathrm{mg} / \mathrm{L}$ at site PHL03. The Stony Clove Creek channel intersected known glacigenic sediment deposits and a hillslope failure a short distance upstream from PHL03. Mean SSCs during low streamflows were less than $15 \mathrm{mg} / \mathrm{L}$ at all sites upstream from PHL02, with the exception of one sampling date. These low SSCs during low streamflows indicate that no active, chronic sources of sediment were present in Stony Clove Creek upstream from PHL02 during 2014. Active chronic sources of sediment are those that contribute sediment to the stream through the range in streamflow conditions, not just during high streamflow. During high streamflow conditions, however, suspended sediment is contributed steadily along the length of Stony Clove Creek.

Longitudinal samples were collected in Stony Clove Creek before, during, and after STRP construction between sites PHL02 and PH0001 (fig. 16). During high streamflows, mean SSCs at sites PHL01, PH0001, and PHL02 were greater than $100 \mathrm{mg} / \mathrm{L}$, a substantial increase from the upstream sites (fig. 16A). During low streamflows, the SSCs at sites PH0001 and PHL01 were greater than $20 \mathrm{mg} / \mathrm{L}$ before the completion of the 2013 Stony Clove STRP but less than $5 \mathrm{mg} / \mathrm{L}$ after the completion of the STRP (fig. 16B). The confluence of Stony Clove and Warner Creeks and hillslope failures in these stream 


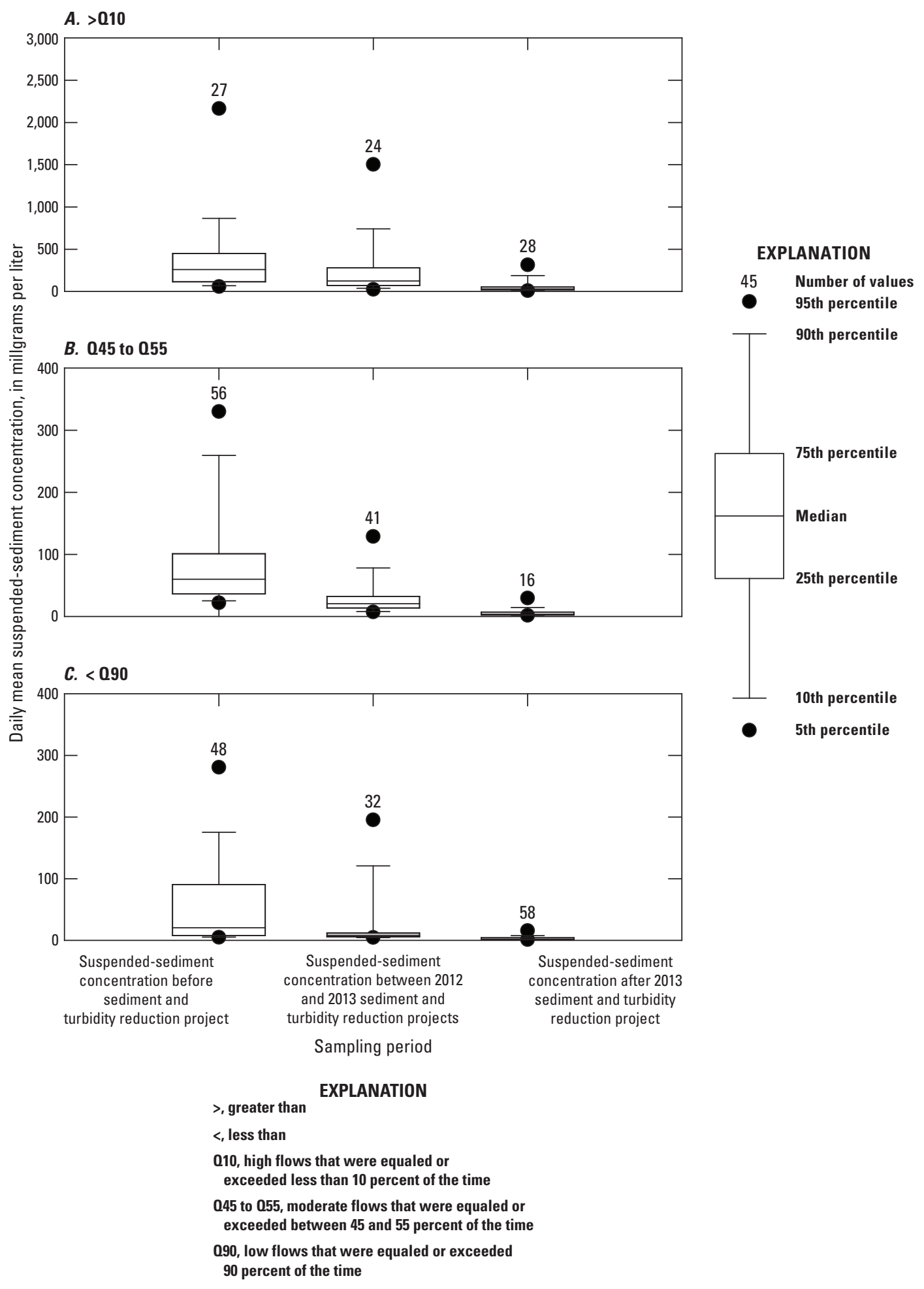

Figure 12. Daily mean suspended-sediment concentration for daily mean streamflow at Stony Clove Creek below 0x Clove at Chichester, New York, before the sediment turbidity reduction projects (STRP), between the 2012 and 2013 STRPs, and after the 2013 STRP. Streamflow was equaled or exceeded $A$, less that 10 percent of the time (greater than 010; high streamflows), $B$, between 45 and 55 percent of the time ( 045 to 055 ; moderate streamflows), and $C, 90$ percent or more of the time (less than 090 , low streamflows). 

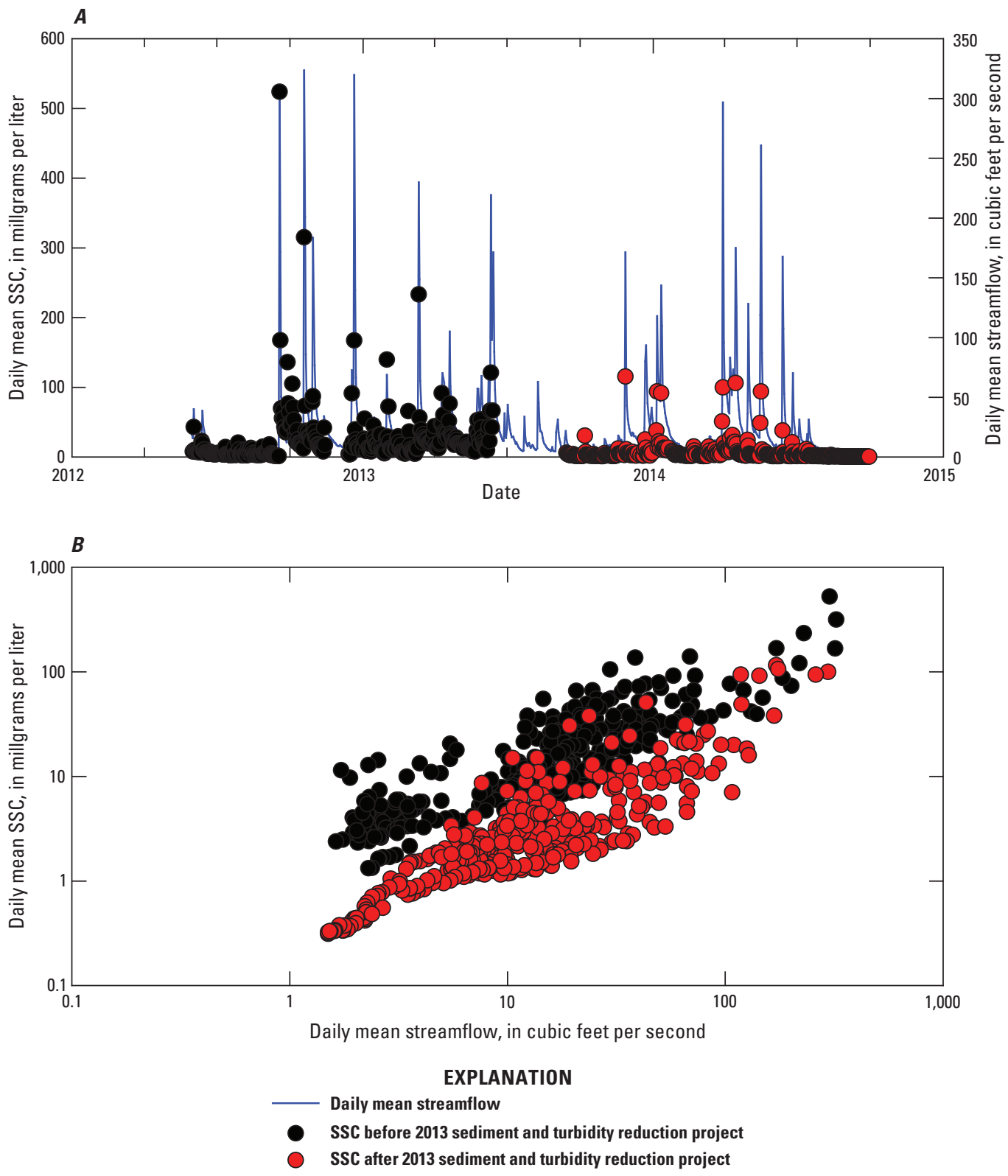

Figure 13. A, daily mean suspended-sediment concentration (SSC) and streamflow and $B$, daily mean SSC as a function of daily mean streamflow before and after the sediment and turbidity reduction project at the Warner Creek near Chichester, New York, streamgage.

reaches were likely sources of sediment episodically during high streamflows and chronically during low streamflows.

The SSCs averaged less than $3 \mathrm{mg} / \mathrm{L}$ during low and high streamflows in the 100 percent forested headwaters of Warner Creek (WAL06; fig. 17A-B). During high streamflows, mean SSC increased downstream from the headwater site to $19 \mathrm{mg} / \mathrm{L}$ at site WAL05, $35 \mathrm{mg} / \mathrm{L}$ at site WAL04, $42 \mathrm{mg} / \mathrm{L}$ at site WAL02, $50 \mathrm{mg} / \mathrm{L}$ at site WA0001, and $60 \mathrm{mg} / \mathrm{L}$ at site WAL01 (fig. 17A). Numerous exposures of glacigenic sediment deposits are intersected by Warner Creek downstream from the headwaters site, likely accounting for the steady increases observed in SSC. During low streamflows, the mean SSC measured at sites was less than $5 \mathrm{mg} / \mathrm{L}$ (fig. 17B). Similar to Stony Clove Creek watershed upstream from site PHL02, data indicate that the Warner Creek watershed does not have one dominant, active, chronic source of sediment that contributes large amounts of suspended sediment throughout all streamflow conditions; however, sediment in the stream steadily increases along the length of Warner Creek during high streamflows (fig. 17A). 


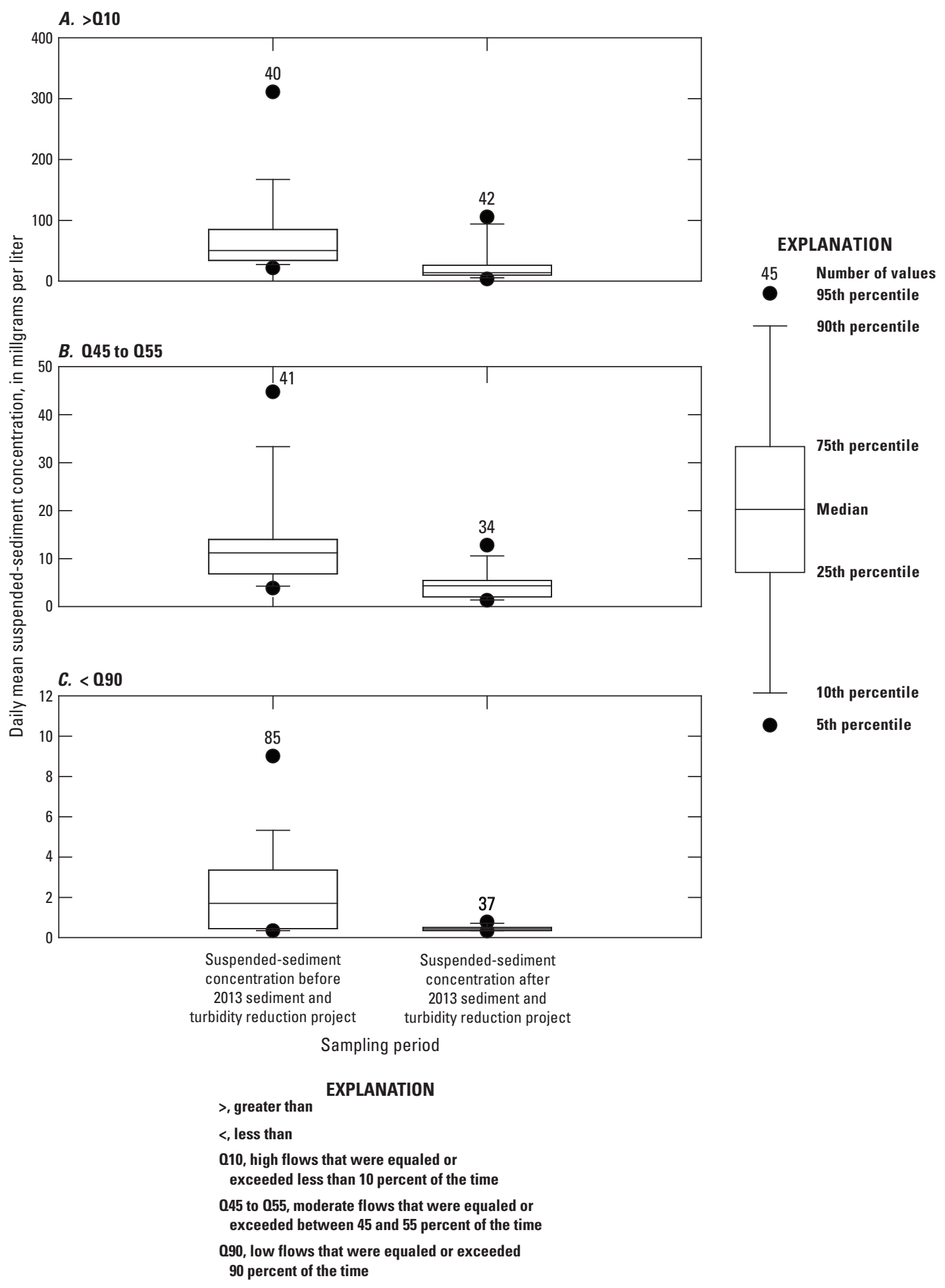

Figure 14. Showing daily mean suspended-sediment concentration for daily mean streamflow at the Warner Creek near Chichester, New York, streamgage before and after the 2013 sediment turbidity reduction project. Streamflow was equaled or exceeded $A$, less that 10 percent of the time (greater than 010; high streamflows), $B$, between 45 and 55 percent of the time (045 to 055; moderate streamflows), and $C, 90$ percent or more of the time (less than Q90, low streamflows). 

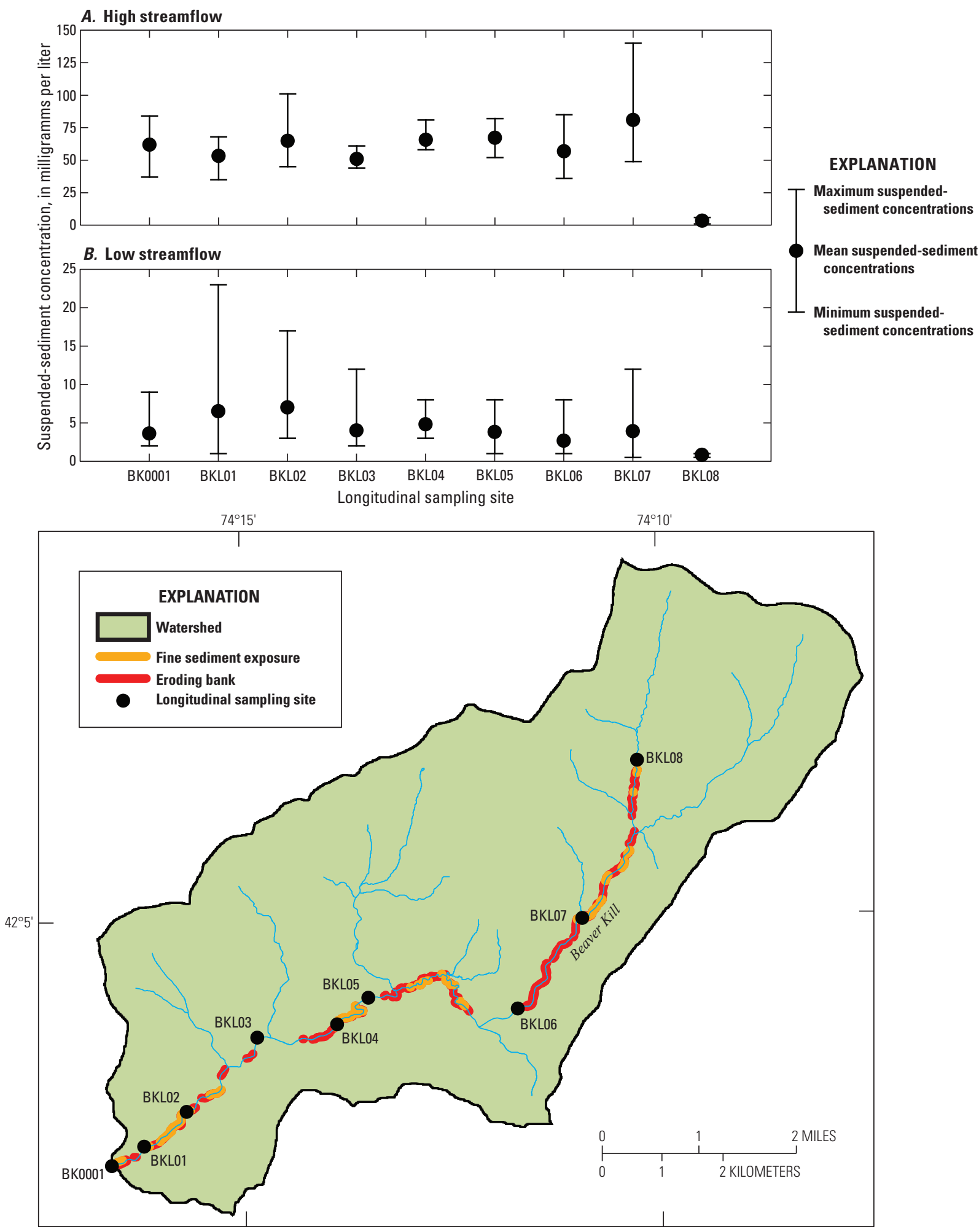

Base from U.S. Geological Survey The National Map digital data, 2016

Figure 15. Longitudinal sampling sites, bank erosion, and fine sediment exposures in the Beaver Kill watershed, New York. The inset map shows minimum, mean, and maximum suspended-sediment concentrations measured at longitudinal sampling sites during $A$, high streamflow and $B$, low streamflow. 

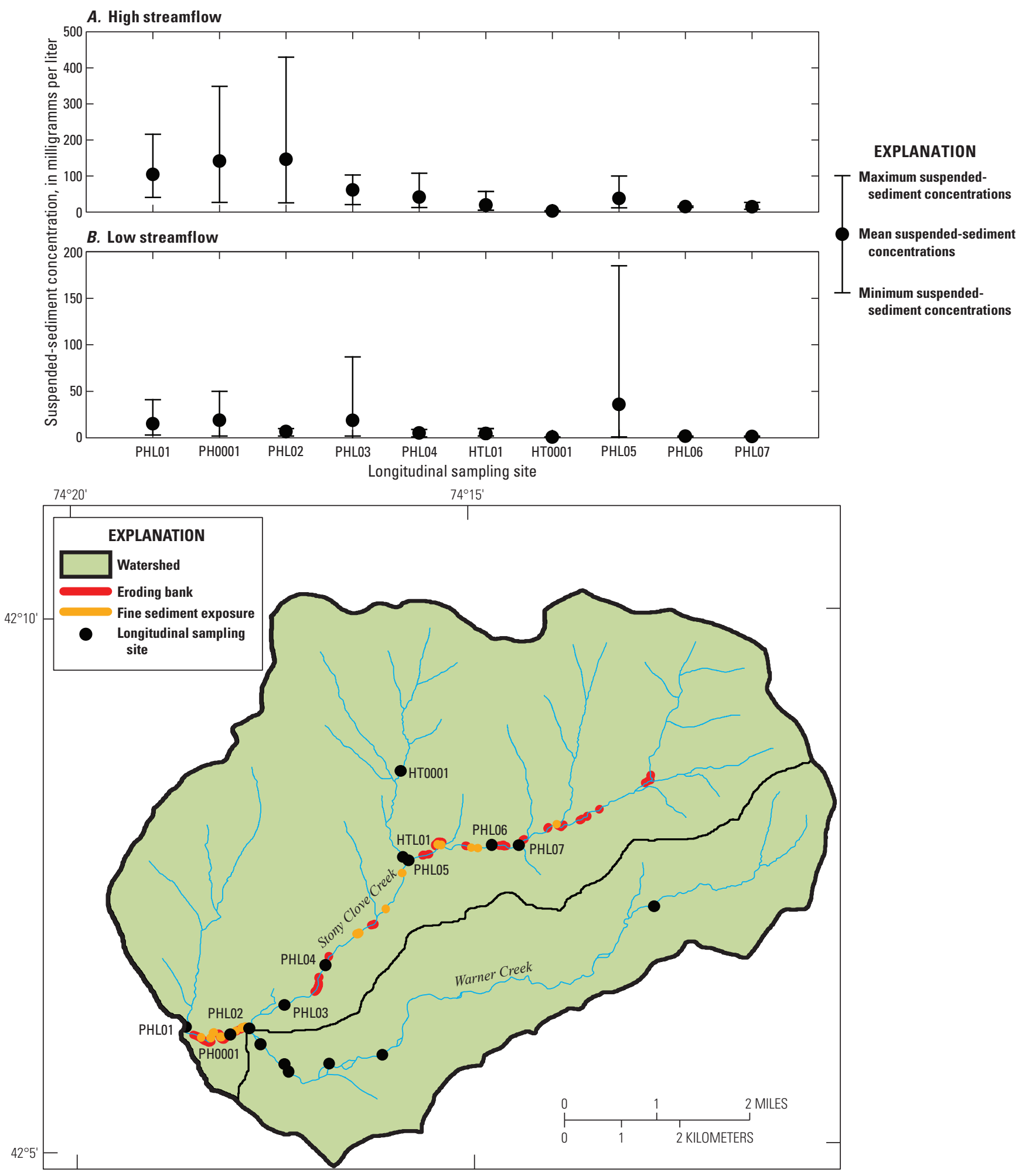

Base from U.S. Geological Survey The National Map digital data, 2016

Figure 16. Longitudinal sampling sites, bank erosion, and fine sediment exposures in the Stony Clove Creek watershed, New York. The inset map shows minimum, mean, and maximum suspended-sediment concentrations measured at longitudinal sampling sites during $A$, high streamflow and $B$, low streamflow. 

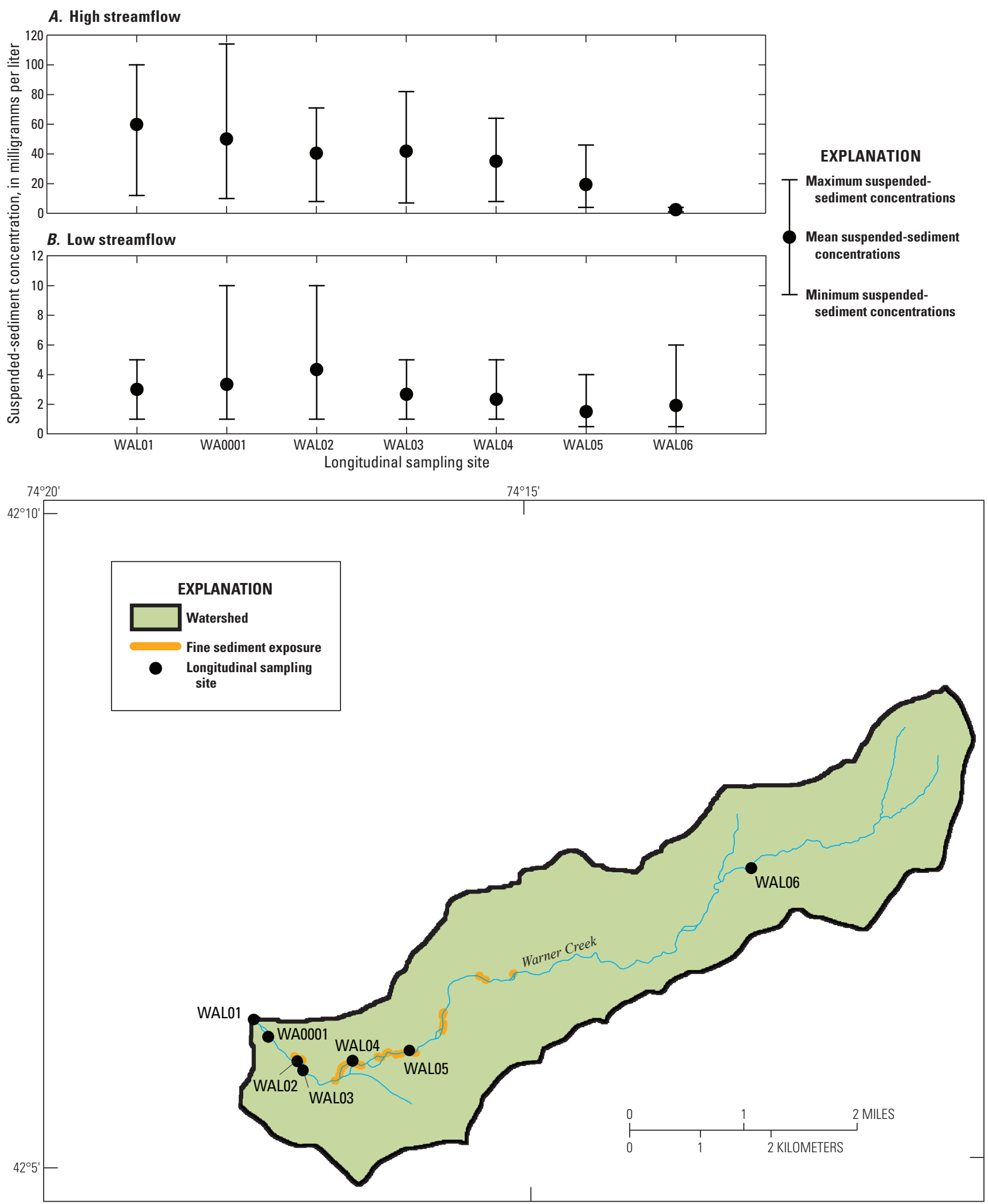

Base from U.S. Geological Survey The National Map digital data, 2016

Figure 17. Longitudinal sampling sites and fine sediment exposures in the Warner Creek watershed, New York. The inset map shows minimum, mean, and maximum suspended-sediment concentrations measured at longitudinal sampling sites during $A$, high streamflow and $B$, low streamflow. 


\section{Summary}

Suspended-sediment concentrations (SSC) and turbidity were monitored within the Beaver Kill, Stony Clove Creek, and Warner Creek tributaries to the upper Esopus Creek, the main source of water to the Ashokan Reservoir, from October 1, 2010, through September 30, 2014. The purpose of the monitoring was to determine the effects of suspended sediment and turbidity reduction projects (STRP) on SSC and turbidity in two of the three streams; no STRPs were constructed in the Beaver Kill. During the study period, four STRPs were completed in the Stony Clove Creek and Warner Creek watersheds. Turbidity-SSC regression equations were developed and used with 15-minute turbidity values to predict 15-minute SSCs. The 15-minute SSCs were then used to calculate daily mean SSCs and daily suspended-sediment loads. Streamflow conditions were significantly different before and after STRP construction; therefore, to evaluate the study results, the data were grouped into low flow, moderate flow, and high flow classes.

Daily mean SSCs significantly decreased in each streamflow class after the STRPs were completed. The completion of the STRPs in the Stony Clover Creek watershed has resulted in significant decreases in daily mean SSCs of nearly 300 milligrams per liter $(\mathrm{mg} / \mathrm{L})$ at high streamflow, about $80 \mathrm{mg} / \mathrm{L}$ at moderate streamflow, and about $40 \mathrm{mg} / \mathrm{L}$ at low streamflow. The completion of the STRP in the Warner Creek watershed has resulted in significant decreases in daily mean SSCs of nearly $40 \mathrm{mg} / \mathrm{L}$ at high streamflow, about $10 \mathrm{mg} / \mathrm{L}$ at moderate streamflow, and about $4 \mathrm{mg} / \mathrm{L}$ at low streamflow.

Suspended-sediment loads in Stony Clove Creek generally were greater than those in Beaver Kill by a factor of 6 to 10 during water years 2010-13. However, after the completion of the STRPs in the Stony Clove Creek watershed, the difference in loads decreased to less than a factor of 2 during water year 2014. Suspended-sediment loads measured during STRP construction periods ranged from 15 to 60 percent of annual loads.

Longitudinal samples were collected along the lengths of each stream to identify chronic and episodic sources of sediment. Background SSCs in the headwaters of all three streams were less than $5 \mathrm{mg} / \mathrm{L}$ through the range in streamflow conditions. The primary sources of SSC in Beaver Kill, Stony Clove Creek, and Warner Creek are the erosion of glacigenic deposits in steep cut banks on the outside of meander bends (hillslope failures). SSC steadily increased downstream from the headwaters of Warner Creek to the confluence with Stony Clove Creek. The most substantial increases in SSC in Stony Clove Creek were downstream from the confluence with Warner Creek where large hillslope failures were the focus of the STRPs.

After the construction of the STRPs in the Stony Clove Creek and Warner Creek watersheds, suspended-sediment concentrations and loads within the watersheds significantly decreased for the range of daily mean streamflow observed during the study period.

\section{References Cited}

Alcott, Emily, Ashton, M.S., and Gentry, B.S., eds., 2013, Natural and engineered solutions for drinking water supplies-Lessons from the northeastern United States and directions for global watershed management: Boca Raton, Fla., CRC Press, 303 p.

Anderson, C.W., 2005, Turbidity, sec. 6.7 of Field measurements: U.S. Geological Survey Techniques of WaterResources Investigations, book 9, chap. A6, 55 p., accessed September 1, 2016, at https://pubs.er.usgs.gov/publication/ twri09A6.7.

Ashokan Watershed Stream Management Program, 2015, Beaver Kill stream management plan-Towns of Woodstock and Shandaken, Ulster County, New York: Shokan, N.Y., Ashokan Watershed Stream Management Program Report SMP1, 139 p., appendixes, accessed September 1, 2016, at http://ashokanstreams.org/publications-resources/ stream-management-plans/.

Baglia, J.W., O'Connell, W., and Chowdhury, S.H., 2014, Effects of groundwater on slope failure in the Stony Clove Basin, Catskill, NY, in Geological Society of America Northeastern Section, annual meeting, 49, Lancaster, Pa., March 23-25, 2014: Geological Society of America Abstracts with Programs, v. 46, no. 2, p. 115.

Cadwell, D.H., and Skiba, J.B., 1986, Surficial geologic map of New York-Albany, N.Y.: New York State Museum Geological Survey Map and Chart Series 40, 1:250,000scale digital data, accessed September 1, 2016, at http://www.nysm.nysed.gov/research-collections/geology/gis.

Cornell Cooperative Extension of Ulster County, 2007, Watershed and stream characterization, v. III of Upper Esopus Creek management plan: Cornell Cooperative Extension of Ulster County, New York City Department of Environmental Protection, and U.S. Army Engineer Research Development Center, 225 p., accessed September 1, 2016, at http://ashokanstreams.org/publications-resources/ stream-management-plans/.

Davis, W.D., and Callinan, C.J., 2013, Diagnostic assessment of Warner Creek, Catskill Mountains, NY-Three years of student conducted research - Conclusions and implications, in Geological Society of America Northeastern Section, annual meeting, 48, Bretton Woods, N.H., March 18-20, 2013: Geological Society of America Abstracts with Programs, v. 45, no 1, p. 131.

Davis, Dan, Knuepfer, P.L.K., Miller, Nicolas, and Vian, Mark, 2009, Fluvial geomorphology of the upper Esopus Creek watershed and implications for stream management, in New York State Geological Association 81st annual meeting field trip guidebook: New York State Geological Society, p. 8.1-8.20, accessed September 1, 2016, at http://www2.newpaltz.edu/ vollmerf/papers/ NYSGA_2009.pdf. 
Davis, Danyelle, McHale, Michael, Siemion, Jason, and Lent, Allison, 2015, A turbidity/suspended sediment reduction strategy for Stony Clove Creek watershed, Catskill Mountains, NY, in Mid-Atlantic Stream Restoration Conference, Baltimore, Md., September 20-22, 2017: Winston-Salem, N.C., Resource Institute, Inc. Web site, accessed September 1, 2016, at http://midatlanticstream.org/?page_id=1355.

De Simone, D.J., Rayburn, J.A., Staley, A.E., Sandstrom, R.M., Kiser, K.E., Carey, C.J.B., Arnold, E.G., and Morrow, Katherin, 2013, Emerging views of Esopus basin glacial history, in Geological Society of America Northeastern Section, annual meeting, 48, Bretton Woods, N.H., March 18-20, 2013, Geological Society of America Abstracts with Programs, v. 45, no. 1, p. 131.

Duan, Naihua, 1983, Smearing estimate-A nonparametric retransformation method: Journal of the American Statistical Association, v. 78, no. 383, p. 605-610.

Edwards, T.K., and Glysson, G.D., 1999, Field methods for measurement of fluvial sediment: U.S. Geological Survey Techniques of Water-Resources Investigations, book 3, chap. C2, 89 p., accessed September 2, 2016, at https://pubs.usgs.gov/twri/twri3-c2/.

Effler, S.W., Perkins, M.G., Ohrazda, N., Brooks, C., Wagner, B.A., Johnson, D.L., Peng, F., and Bennett, A., 1998, Turbidity and particle signatures imparted by runoff events in Ashokan Reservoir, NY: Journal of Lake and Reservoir Management, v. 14, nos. 2-3, p. 254-265.

Green County Soil and Water Conservation District, 2005, Stony Clove Creek stream management plan: Green County Soil and Water Conservation District, Cornell Cooperative Extension of Ulster County, 2 v., [variously paged], accessed September 1, 2016, at http://www.catskillstreams.org/stonyclovesmp.html.

Guy, R.P., 1969, Laboratory theory and methods for sediment analysis: U.S. Geological Survey Techniques of Water-Resources Investigations, book 5, chap. C1, 59 p., at http://pubs.usgs.gov/twri/twri5c1/.

Haskins, M.N., and Vollmer, F.W., 2013, Joint and bedrock control of topography, drainage patterns and surface hydrology, Warner Creek and Stony Clove drainage basins, Catskill Mountains, eastern New York, in Geological Society of America Northeastern Section, annual meeting, 48, Bretton Woods, N.H., March 18-20, 2013, Geological Society of America Abstracts with Programs, v. 45, no. 1, p. 131.

Helsel, D.R., and Hirsch, R.M., 2002, Statistical methods in water resources: U.S. Geological Survey Techniques of Water-Resources Investigations, book 4, chap. A3, 510 p., accessed September 2, 2016, at http://water.usgs.gov/pubs/ twri/twri4a3/.
Hewes, Christopher, and McGlinn, Lawrence, 2013, Historical 3D modeling of erosion in Stony Clove Creek for sediment volume analysis using GIS, in Geological Society of America Northeastern Section, annual meeting, 48, Bretton Woods, N.H., March 18-20, 2013, Geological Society of America Abstracts with Programs, v. 45, no. 1, p. 131.

Kiekhaefer, R.L., and Chowdhury, Shafiul, 2013, Role of groundwater and surface water interactions on slope stability in the Stony Clove Creek, Chichester, NY, in Geological Society of America Northeastern Section, annual meeting, 48, Bretton Woods, N.H., March 18-20, 2013: Geological Society of America Abstracts with Programs, v. 45, no. 1, p. 131.

Koltun, G.F., Eberle, Michael, Gray, J.R., and Glysson, G.D., 2006, User's manual for the graphical constituent loading analysis system (GCLAS): U.S. Geological Survey Techniques and Methods, book 4, chap. C1, 51 p., accessed September 2, 2016, at http://pubs.usgs.gov/tm/2006/tm4C1/.

McHale, M.R., and Siemion, Jason, 2010, U.S. Geological Survey Catskill/Delaware water-quality network-Waterquality report water year 2006: U.S. Geological Survey Data Series 497, 36 p., accessed September 2, 2016, at https://pubs.er.usgs.gov/publication/ds497.

McHale, M.R., and Siemion, Jason, 2014, Turbidity and suspended sediment in the upper Esopus Creek watershed, Ulster County, New York: U.S. Geological Survey Scientific Investigations Report 2014-5200, 42 p., accessed September 1, 2016, at https://doi.org/10.3133/sir20145200.

Mukundan, Rajith, Pierson, D.C., Schneiderman, E.M., O’Donnell, D.M., Pradhanang, S.M., Zion, M.S., and Matonse, A.H., 2013, Factors affecting storm event turbidity in a New York City water supply stream: Catena, v. 107, p. $80-88$.

Neel, Abbye, Davis, Danyelle, Korren, Caitlyn, and Callinan, C.J., 2013, Diagnostic assessment of Warner Creek's fluvial geomorphic response to 2010-2012 hydrology in the Catskill Mountains of New York State, in Geological Society of America Northeastern Section, annual meeting, 48, Bretton Woods, N.H., March 18-20, 2013: Geological Society of America Abstracts with Programs, v. 45, no. 1, p. 131 .

New York City, 2014, World class water: New York City Web page, accessed September 1, 2016, at http://www.nyc.gov/ $\mathrm{html} /$ waterforthefuture/world-class-water.shtml.

Rantz, S.E., and others, 1982, Computation of discharge, v. 2 of Measurement and computation of streamflow: U.S. Geological Survey Water-Supply Paper 2175, p. 285-631, at http://pubs.usgs.gov/wsp/wsp2175/. 
Rasmussen, P.P., Gray, J.R., Glysson, G.D., and Ziegler, A.C., 2009, Guidelines and procedures for computing time-series suspended-sediment concentrations and loads from instream turbidity-sensor and streamflow data: U.S. Geological Survey Techniques and Methods, book 3, chap. C4, 53 p., accessed September 2, 2016, at http://pubs.usgs.gov/ $\mathrm{tm} / \mathrm{tm} 3 \mathrm{c} 4 /$.

Samal, N.R., Matonse, A.H., Mukundan, Rajith, Zion, M.S., Pierson, D.C., Gelda, R.K., and Schneiderman, E.M., 2013, Modeling potential effects of climate change on winter turbidity loading in the Ashokan Reservoir, NY: Hydrological Processes, v. 27, no. 21, p. 3061-3074.

Shreve, E.A., and Downs, A.C., 2005, Quality-assurance plan for the analysis of fluvial sediment by the U.S. Geological Survey Kentucky Water Science Center Sediment Laboratory: U.S. Geological Survey Open-File Report 2005-1230, 28 p., accessed September 2, 2016, at https://doi.org/10.3133/ofr20051230.

Staley, A.E., Rayburn, J.A., DeSimone, D.J., and McGlinn, Lawrence, 2013, 3D modeling of surficial sediments in the Stony Clove basin, Catskill Mountain region of NY, in Geological Society of America Northeastern Section annual meeting, 48, Bretton Woods, N.H., March 18-20, 2013: Geological Society of America Abstracts with Programs, v. 45 , no. 1 , p. 131.

U.S. Environmental Protection Agency, 2007, New York City filtration avoidance determination: U.S. Environmental Protection Agency Web page, accessed September 1, 2016, at https://archive.epa.gov/region02/water/nycshed/web/html/ filtad.html.

U.S. Geological Survey, 2016a, 01362487, Beaver Kill at Mount Tremper NY - Discharge and suspended sediment data: U.S. Geological Survey National Water Information System Web interface, accessed September 1, 2016, at http://waterservices.usgs.gov/nwis/dv/?format=excel\& sites $=01362487 \&$ startDT $=2010-10-01$ \&endDT $=2014-09$ 30\&parameterCd=00060,99409,80297.
U.S. Geological Survey, 2016b, 01362370, Stony Clove Creek Blw Ox Clove at Chichester NY-Discharge and suspended sediment data: U.S. Geological Survey National Water Information System Web interface, accessed September 1, 2016, at http://waterservices.usgs.gov/nwis/dv/?format=ex cel\&sites $=01362370 \&$ startDT $=2010-10-01$ \&endDT $=2014-$ 09-30\&parameterCd=00060,99409,80297.

U.S. Geological Survey, 2016c, 01362357, Warner Creek near Chichester NY-Discharge and suspended sediment data: U.S. Geological Survey National Water Information System Web interface, accessed September 1, 2016, at http://waterservices.usgs.gov/nwis/dv/?format=excel\& sites $=01362357 \&$ startDT $=2010-10-01 \&$ endDT $=2014-09$ 30\&parameterCd=00060,99409,80297.

U.S. Geological Survey, 2016d, USGS water data for the nation: U.S. Geological Survey National Water Information System Web interface, accessed September 1, 2016, at https://doi.org/10.5066/F7P55KJN.

Wagner, R.J., Boulger, R.W., Jr., Oblinger, C.J., and Smith, B.A., 2006, Guidelines and standard procedures for continuous water-quality monitors - Station operation, record computation, and data reporting: U.S. Geological Survey Techniques and Methods, book 1, chap. D3, 51 p., appendixes, accessed September 2, 2016, at http://pubs.usgs.gov/ $\mathrm{tm} / 2006 / \mathrm{tm} 1 \mathrm{D} 3 /$.

Wilde, F.D., Radtke, D.B., Gibs, J., and Iwatsubo, R.T., eds., 1999, Collection of water samples: U.S. Geological Survey Techniques of Water-Resources Investigations, book 9, chap. A4, 231 p., accessed September 1, 2016, at http://pubs.water.usgs.gov/twri9A4/. 


\section{Appendixes}

Appendix 1. Suspended-Sediment Concentrations and Concurrent Turbidity for the Beaver Kill, Stony Clove Creek, and Warner Creek Watersheds, New York, 2010-14

[Available for download at https://doi.org/10.3133/sir20165157.]

Appendix 2. Streamflow Monitoring in the Beaver Kill, Stony Clove Creek, and Warner Creek Watersheds, New York 



\section{Appendix 2. Streamflow Monitoring in the Beaver Kill, Stony Clove Creek, and Warner Creek Watersheds, New York}

Table 2-1. Longitudinal sampling sites and U.S. Geological Survey streamgages in the Beaver Kill, Stony Clove Creek, and Warner Creek watersheds, New York.

[USGS, U.S. Geological Survey; ID, identification number; WA, Warner Creek; BK, Beaver Kill; PH, Stony Clove Creek; L, longitudinal]

\begin{tabular}{cl}
\hline Sampling location & USGS streamgage ID \\
\hline WAL01 & 420607074174901 \\
WA0001 & 01362357 \\
WAL02 & 420547074172301 \\
WAL03 & 01362356 \\
WAL04 & 420547074164901 \\
WAL05 & 420551074161401 \\
WAL06 & 420713074124301 \\
BK0001 & 01362487 \\
BKL01 & 420258074161301 \\
BKL02 & 420316074154201 \\
BKL03 & 420356074145101 \\
BKL04 & 420403074135301 \\
BKL05 & 420417074133101 \\
BKL06 & 420410074114301 \\
BKL07 & 420459074105601 \\
BKL08 & 420623074101501 \\
PHL01 & 420500074185701 \\
PH0001 & 01362370 \\
PHL02 & 420604074180401 \\
PHL03 & 01362350 \\
PHL04 & 420642074165101 \\
PHL05 & 420740074154801 \\
HTL01 & 420742074155201 \\
HT0001 & 01362342 \\
PHL06 & 01362332 \\
PHL07 & 01362330 \\
\hline & \\
\hline &
\end{tabular}


Table 2-2. Instantaneous streamflow at monitoring stations in the Beaver Kill, Stony Clove Creek, and Warner Creek watersheds, New York.

[Streamflow in cubic feet per second; --, no data]

\begin{tabular}{|c|c|c|c|c|c|c|c|c|}
\hline \multicolumn{3}{|c|}{ Beaver Kill } & \multicolumn{3}{|c|}{ Stony Clove Creek } & \multicolumn{3}{|c|}{ Warner Creek } \\
\hline $\begin{array}{l}\text { Sampling } \\
\text { date }\end{array}$ & $\begin{array}{c}\text { Streamflow } \\
\text { at start of } \\
\text { sampling }\end{array}$ & $\begin{array}{c}\text { Streamflow } \\
\text { at end of } \\
\text { sampling }\end{array}$ & $\begin{array}{l}\text { Sampling } \\
\text { date }\end{array}$ & $\begin{array}{c}\text { Streamflow } \\
\text { at start of } \\
\text { sampling }\end{array}$ & $\begin{array}{l}\text { Streamflow } \\
\text { at end of } \\
\text { sampling }\end{array}$ & $\begin{array}{l}\text { Sampling } \\
\text { date }\end{array}$ & $\begin{array}{c}\text { Streamflow } \\
\text { at start of } \\
\text { sampling }\end{array}$ & $\begin{array}{c}\text { Streamflow } \\
\text { at end of } \\
\text { sampling }\end{array}$ \\
\hline $5 / 31 / 2012$ & -- & -- & $5 / 30 / 2012$ & 87 & 82 & $5 / 30 / 2012$ & 22 & 21 \\
\hline $6 / 13 / 2012$ & 110 & 81 & $6 / 13 / 2012$ & 95 & 84 & $6 / 13 / 2012$ & 38 & 35 \\
\hline 9/19/2012 & 325 & 235 & $9 / 19 / 2012$ & 489 & 354 & 9/19/2012 & 141 & 120 \\
\hline $9 / 12 / 2013$ & 18 & 18 & $9 / 12 / 2013$ & 35 & 32 & $9 / 12 / 2013$ & 9 & 9 \\
\hline $12 / 22 / 2013$ & 276 & 280 & $12 / 22 / 2013$ & 307 & 324 & $12 / 22 / 2013$ & 86 & 98 \\
\hline $3 / 31 / 2014$ & 280 & 257 & $3 / 30 / 2014$ & 580 & 575 & $3 / 30 / 2014$ & 277 & 200 \\
\hline $5 / 29 / 2014$ & 27 & 27 & $5 / 29 / 2014$ & 61 & 59 & $5 / 29 / 2014$ & 13 & 14 \\
\hline
\end{tabular}


For additional information write to: Director, New York Water Science Center U.S. Geological Survey

425 Jordan Road

Troy, NY 12180-8349

Email: dc_ny@usgs.gov

Information requests:

(518) 285-5602

or visit our Web site at: http://ny.water.usgs.gov

Publishing support by:

The Pembroke Publishing Service Center 
